\title{
Sources of long-lived atmospheric VOCs at the rural boreal forest site, SMEAR II
}

\author{
J. Patokoski ${ }^{1}$, T. M. Ruuskanen ${ }^{1}$, M. K. Kajos ${ }^{1}$, R. Taipale ${ }^{1}$, P. Rantala ${ }^{1}$, J. Aalto ${ }^{2}$, T. Ryyppö ${ }^{3}$, T. Nieminen ${ }^{1,4}$, \\ H. Hakola ${ }^{5}$, and J. Rinne ${ }^{1,5,6}$ \\ ${ }^{1}$ Division of Atmospheric Sciences, Department of Physics, University of Helsinki, P.O. Box 64, \\ 00014 University of Helsinki, Helsinki, Finland \\ ${ }^{2}$ Department of Forest Sciences, University of Helsinki, Helsinki, Finland \\ ${ }^{3}$ Finnish Meteorological Institute, Arctic Research Centre, Tähteläntie 62, 99600 Sodankylä, Finland \\ ${ }^{4}$ Helsinki Institute of Physics, P.O. Box 64, 00014 University of Helsinki, Helsinki, Finland \\ ${ }^{5}$ Finnish Meteorological Institute, P.O. Box 503, 00101 Helsinki, Finland \\ ${ }^{6}$ Department of Geosciences and Geography, University of Helsinki, Helsinki, Finland
}

Correspondence to: T. M. Ruuskanen (taina.ruuskanen@ @elsinki.fi)

Received: 19 February 2015 - Published in Atmos. Chem. Phys. Discuss.: 26 May 2015

Revised: 14 October 2015 - Accepted: 26 October 2015 - Published: 7 December 2015

\begin{abstract}
In this study a long-term volatile organic compound (VOCs) concentration data set, measured at the SMEAR II (Station for Measuring Ecosystem-Atmosphere Relations) boreal forest site in Hyytiälä, Finland during the years 2006-2011, was analyzed in order to identify source areas and profiles of the observed VOCs. VOC mixing ratios were measured using proton transfer reaction mass spectrometry. Four-day HYSPLIT 4 (Hybrid Single Particle Lagrangian Integrated Trajectory) backward trajectories and the Unmix 6.0 receptor model were used for source area and source composition analysis. Two major forest fire events in Russia took place during the measurement period. The effect of these fires was clearly visible in the trajectory analysis, lending confidence to the method employed with this data set. Elevated volume mixing ratios (VMRs) of non-biogenic VOCs related to forest fires, e.g. acetonitrile and aromatic VOCs, were observed. Ten major source areas for longlived VOCs (methanol, acetonitrile, acetaldehyde, acetone, benzene, and toluene) observed at the SMEAR II site were identified. The main source areas for all the targeted VOCs were western Russia, northern Poland, Kaliningrad, and the Baltic countries. Industrial areas in northern continental Europe were also found to be source areas for certain VOCs. Both trajectory and receptor analysis showed that air masses
\end{abstract}

from northern Fennoscandia were less polluted with respect to both the VOCs studied and other trace gases $\left(\mathrm{CO}, \mathrm{SO}_{2}\right.$ and $\mathrm{NO}_{x}$ ), compared to areas of eastern and western continental Europe, western Russia, and southern Fennoscandia.

\section{Introduction}

Volatile organic compounds (VOCs) in the atmosphere have several sources, both biogenic and anthropogenic. On a global scale the biogenic emissions are estimated to be an order of magnitude higher than the anthropogenic ones (Guenther et al., 1995). The main biogenic sources are forests (Simpson et al., 1999), to a lesser degree, crops (Guenther et al., 1995), and algae in aquatic ecosystems (Fink et al., 2007). However, in many circumstances, including winter in northern latitudes and air pollution events, anthropogenic emissions can be dominant. The most important non-biogenic VOC sources are traffic, biomass burning (especially forest fires), extraction and refining of fossil fuels, and evaporation of solvents (Blake et al., 2009). Once emitted, the VOCs are transported and oxidized in photochemical processes during this transport. The main oxidants for VOCs in the atmosphere are ozone $\left(\mathrm{O}_{3}\right)$, and the hydroxyl $(\mathrm{OH})$ and 
nitrate $\left(\mathrm{NO}_{3}\right)$ radicals (Atkinson and Arey, 2003). Depending on their reactivity with these oxidants, some VOCs have a relatively long lifetime, from a few days to a few months, and can be transported over long distances. In order to study this atmospheric transport and to identify the source areas of the measured concentrations, trajectory analysis has been widely used (Stohl, 1996; Stohl and Seibert, 1998).

The source areas which VOCs are emitted from may comprise of areas with well-defined industrial sources, of densely populated urban areas with a mixture of various source elements such as industry, power plants, and vehicles (Baker et al., 2008), or of areas with high biogenic emission rates. Furthermore, areas with forest fires may show up as important source areas during fire episodes (de Gouw et al., 2006). Thus, the importance of different source areas may vary temporally, due to seasonal variations in the biogenic activity of plants, variations in anthropogenic activity or forest fire episodes, and meteorological conditions.

The SMEAR II (Station for Measuring EcosystemAtmosphere Relations) site, located in a rural environment in a boreal forest in southern Finland, has been used for 2 decades to investigate atmospheric processes leading to aerosol particle formation and growth. At this site winters typically are characterized by stronger anthropogenic influence, e.g. from heating, whereas biogenic activity is more pronounced in the summer. There is ample evidence that biogenic VOCs contribute to these processes at this site (e.g. Tunved et al., 2006; Ehn et al., 2014). However, there is also evidence that emissions and atmospheric concentrations of some VOCs generally labelled as biogenic, such as monoterpenes, are occasionally affected by anthropogenic processes (Liao et al., 2011; Haapanala et al., 2012). Furthermore, many VOCs observed at the site, with a relatively long lifetime, are known to have both biogenic and anthropogenic sources. These VOCs include, e.g. methanol, acetone and acetaldehyde. As these compounds can be transported over thousands of kilometres, their atmospheric concentrations observed at SMEAR II are likely to be influenced by distant anthropogenic emissions in addition to more local biogenic and anthropogenic sources. Previously, Ruuskanen et al. (2009) have observed that there is indication of longrange transport of VOCs from continental Europe to Finland. Also Hellén et al. (2006) observed that most of the atmospheric benzene in urban site in Helsinki originated from distant sources. During long-range transport, the VOCs in air masses coming to the SMEAR II site are often at least partly oxidized. Thus the observed VOCs may have also secondary chemical sources in addition to direct emissions.

The volume mixing ratios (VMRs) of VOCs have been studied at SMEAR II earlier, e.g. by Rinne et al. (2005); Ruuskanen et al. (2009); Hakola et al. $(2009,2012)$ and Hellèn et al. (2004). These studies have only made use of short data sets, with the exception of those by Hakola et al. (2009, 2012), thus not allowing for studies of variations from annual to inter-annual scales. Of the two long-term studies, Hakola et al. (2012) utilized continuous measurements by an in situ gas chromatograph and Hakola et al. (2009) used noon-time air samples and laboratory analysis. Both of these studies measured only terpenoid compounds with short atmospheric lifetimes. The analysis of source areas of oxygenated compounds with longer atmospheric lifetimes has not been previously feasible, as long-term data sets on VMRs of several compounds have not been available.

Thus our aim in this study is to investigate the source profiles and source areas of relatively long-lived VOCs (methanol, acetaldehyde, acetone, toluene, benzene) observed at the SMEAR II site by using VOC VMR data covering several years (2006-2011). The specific aims of this study are (1) to identify the main source areas of VOCs observed at SMEAR II, (2) to investigate how these sources coincide with, e.g. wildfires and biomass burning, and major urban and industrial areas and to (3) to determine the biogenic vs. anthropogenic influence by determining the source profiles of VOCs in relation to other trace gases.

The focus of the research conducted at SMEAR II station is atmosphere-biosphere interactions and the aerosol formation and growth processes in the boreal climate zone. While many studies have focused on the influence of local to regional sources on the observed trace gases concentrations (Patokoski et al., 2014; Liao et al., 2011; Eerdekens et al., 2009; Hakola et al., 2009, 2012), this study aims at identifying source areas in regional to continental scale and focuses also on characterizing the effect of long range transport.

\section{Methods}

\subsection{Measurements site}

VOC VMRs were measured at the SMEAR II site in Finland during the years 2006-2011. SMEAR II is a rural measurement station located in a boreal forest in Hyytiälä, southern Finland $\left(61^{\circ} 51^{\prime} \mathrm{N}, 24^{\circ} 17^{\prime} \mathrm{E}, 180 \mathrm{ma}\right.$ a.s.l.). A detailed description of the site is given by, e.g. Hari and Kulmala (2005). The site is located $220 \mathrm{~km}$ north-west of Helsinki and $60 \mathrm{~km}$ north-east of Tampere, which, with a population of about 200000 , is the largest city near the site. Continuous long-term measurements of trace gases, aerosol particles and gas exchange between the atmosphere and the biosphere have been carried out at the SMEAR II since the mid-1990s (Vesala et al., 1998). The forest at the station is dominated by Scots pine (Pinus sylvestris), sown in 1962 (Bäck et al., 2012). There is also some Norway spruce (Picea abies), aspen (Populus tremula), and birch (Betula sp.) at the site (Hari and Kulmala, 2005). The canopy height is about $18 \mathrm{~m}$. Within a square of $40 \mathrm{~km} \times 40 \mathrm{~km}$ centred on the station $23 \%$ of the area is covered by pine forests, $26 \%$ by spruce forest, and $21 \%$ by mixed forest (Haapanala et al., 2007). Agriculture and water bodies cover 10 and $13 \%$, respectively. 
Table 1. Detection limits $\left(\mathrm{ppb}_{\mathrm{v}}\right)$ for $1 \mathrm{~h}$ averages of the measured VOCs during the measurement periods. Percentages of values below detection limit are presented in brackets.

\begin{tabular}{|c|c|c|c|c|}
\hline VOC & $\begin{array}{l}\text { DL1 } \\
\text { (12 Jun- } \\
26 \text { Sep 2006) }\end{array}$ & $\begin{array}{l}\text { DL2 } \\
\text { (29 Nov 2006- } \\
10 \text { Jul 2007) }\end{array}$ & $\begin{array}{l}\text { DL3 } \\
\text { (12 Jul 2007- } \\
\text { 22 Jun 2009) }\end{array}$ & $\begin{array}{l}\text { DL4 } \\
\text { (28 May 2010- } \\
29 \text { Dec 2011) }\end{array}$ \\
\hline Methanol & $0.07(1 \%)$ & $0.06(1 \%)$ & $0.07(1 \%)$ & $0.1(3 \%)$ \\
\hline Acetonitrile & & & $0.004(1 \%)$ & $0.005(4 \%)$ \\
\hline Acetaldehyde & $0.02(2 \%)$ & $0.02(1 \%)$ & $0.02(1 \%)$ & $0.03(1 \%)$ \\
\hline Acetone & $0.02(1 \%)$ & $0.01(1 \%)$ & $0.02(1 \%)$ & $0.03(1 \%)$ \\
\hline Benzene & $0.005(3 \%)$ & $0.003(1 \%)$ & $0.005(3 \%)$ & $0.006(2 \%)$ \\
\hline Toluene & $0.02(73 \%)$ & $0.01(1 \%)$ & $0.02(22 \%)$ & $0.02(4 \%)$ \\
\hline Monoterpenes & $0.01(3 \%)$ & $0.01(19 \%)$ & $0.01(4 \%)$ & $0.02(12 \%)$ \\
\hline
\end{tabular}

\subsection{Instrumentation and sampling}

The VOC VMRs were measured with a quadrupole proton transfer reaction mass spectrometer (PTR-MS, Ionicon Analytik GmbH, Austria, Lindinger et al., 1998a). PTR-MS uses the hydronium ion $\left(\mathrm{H}_{3} \mathrm{O}^{+}\right)$as a primary reactant ion. VOCs with a larger proton affinity than that of water will readily react with $\mathrm{H}_{3} \mathrm{O}^{+}$(Lindinger et al., 1998a, b). This is a a soft ionization technique, and most compounds are not fragmented by it (Tani et al., 2003). The reactant and the product ions are mass filtered with a quadrupole mass spectrometer and detected with a secondary electron multiplier (SEM). Product ions are protonated, and, therefore, methanol, for example, is identified at mass to charge ratio $(m / z$, later denoted $m) m$ of 33 . During the measurements the PTR-MS was calibrated with a VOC calibration gas mixture at regular weekly or biweekly intervals. During the period 2006-2011 four different VOC mixtures, which all included 16-18 VOCs and were all manufactured by ApelRiemer Environmental Inc., USA, were used. Calibration gas mixtures included all the compounds studied here. A detailed description of the calibration procedure and the VMR calculation methodology is presented by Taipale et al. (2008). The following settings were used during the measurements: $U_{\text {drift }}$ varied from 450 to $525 \mathrm{~V}$ (mean value $479 \mathrm{~V}$ ), temperature of drift tube was $50^{\circ} \mathrm{C}, \mathrm{E} / \mathrm{N}$ range varied from 105 to $130 \mathrm{Td}$ (mean value $110 \mathrm{Td}$ ) and normalized sensitivity for, e.g. acetone varied from 18 to $40 \mathrm{ncpsppb}_{\mathrm{v}}^{-1}$ (mean value $\left.28 \mathrm{ncpsppb}_{\mathrm{v}}^{-1}\right)$. Detection limits for studied VOCs are presented in Table 1 . The instrument was calibrated every time when settings were changed, taking into account the changes in the sensitivity and cancelling the effect of the changes in $\mathrm{E} / \mathrm{N}$ to the measured VMRs. Thus the fragmentation and clustering was always taken into account when calculating VMRs.

Six of the measured masses were analyzed in this study: $m$ 33, $m 42, m 45, m 59, m 79$, and $m 93$ a.m.u, which have been identified as methanol, acetonitrile, acetaldehyde, acetone, benzene, and toluene, respectively (de Gouw and
Warneke, 2007). In addition $m$ 137, attributed to monoterpenes, was used as ancillary data in the analysis.

PTR-MS and GC-MS (Gas chromatography mass spectrometer) concentration measurements conducted previously in Hyytiälä have agreed well for monoterpenes (Rinne et al., 2005., Ruuskanen et al., 2005), as well as for methanol, acetaldehyde, acetone, benzene, and toluene (Kajos et al., 2015). These VOCs, excluding monoterpenes, have relatively long lifetimes, and their sources were investigated with HYSPLIT 4 (Hybrid Single Particle Lagrangian Intergrated Trajectory) trajectory analysis and the Unmix 6.0 receptor model. One-hour median mixing ratios were calculated for the analysis. All the data are presented in local standard time $(\mathrm{UTC}+2 \mathrm{~h})$. There are some gaps in the data due to maintenance, some technical problems, and the usage of the PTRMS in other measurement campaigns (Fig. 1). Data quality was checked, and data were filtered by removing values below the detection limit. The detection limits for the measurement periods are presented in Table 1.

During the years 2006-2009 the VMRs of the VOCs were measured from a scaffolding tower at a height of $22 \mathrm{~m}$ above the ground. From summer 2006 to spring 2007 the measurement sequence consisted of $1 \mathrm{~h}$ of atmospheric VMR measurements followed by $1 \mathrm{~h}$ of disjunct eddy covariance measurements. Thus, VMR data were obtained every second hour. The sampling protocol was changed in March 2007 when a branch chamber measuring emission from a Scots pine shoot was included in the measurement cycle. Thereafter the atmospheric VOC VMRs were measured every third hour instead of every second hour. In May 2010 the sampling protocol was changed again when the instrument was transported to another measurement cabin. At the same time the sampling inlet was moved about $50 \mathrm{~m}$ into another tower, with the inlet at $33.6 \mathrm{~m}$ above ground. This sampling height was used for measurements during years 2010-2011. During the years 2010-2011 the atmospheric VMRs used in this work were measured every third hour. These measurement heights were chosen for analysis because they are more representative for atmospheric surface layer concentrations affected by, e.g. long distance transport, than concentrations 


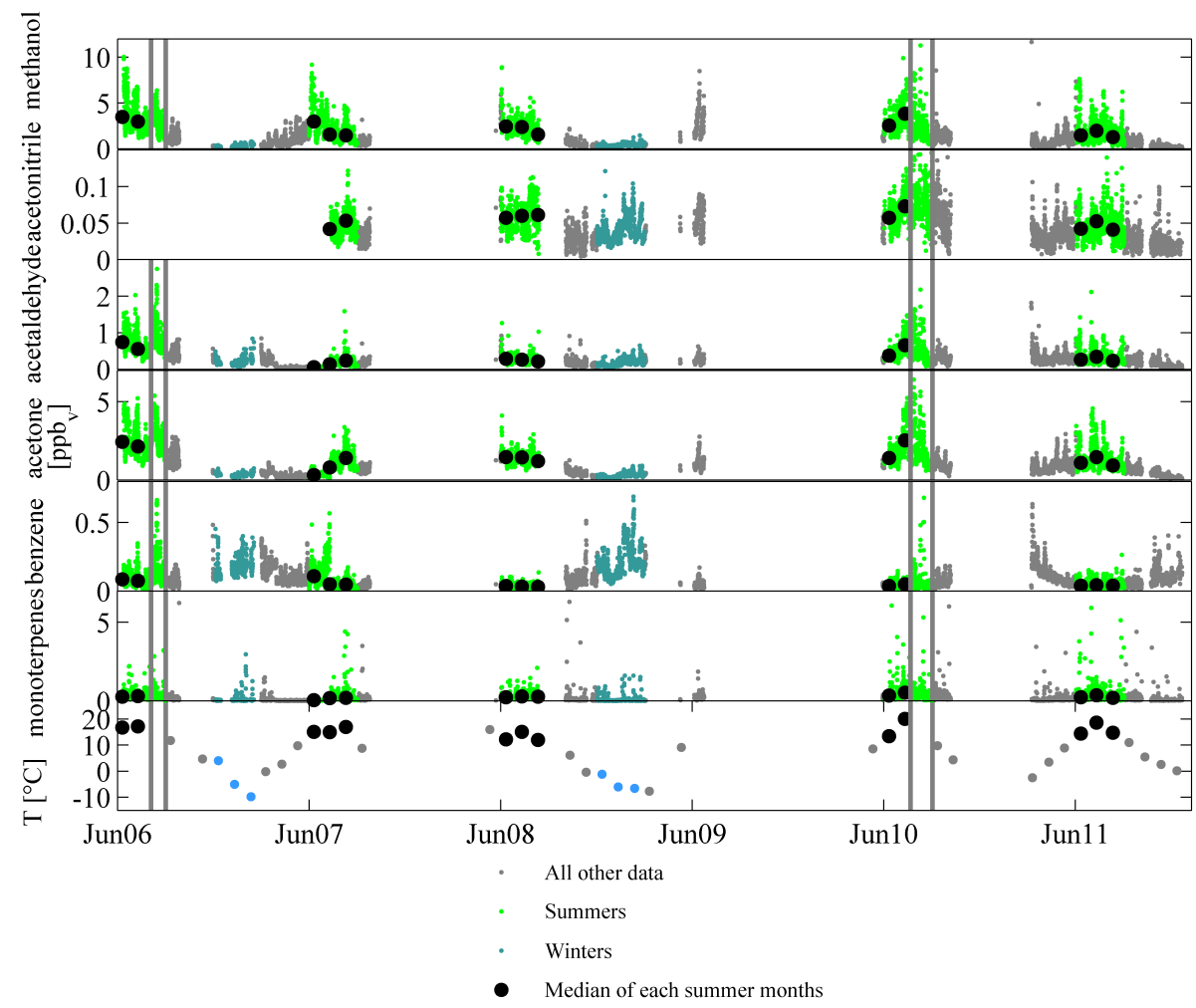

Figure 1. Time-series of the VMRs of the VOC studied during the measurement period. Summertime data used in source area analysis are marked in green and winter data in light blue. Data from other seasons are marked in grey. The monthly medians of the summer months are marked with black dots. The forest fire periods in the summers of 2006 and 2010 are marked with grey vertical lines.

inside the canopy which may be affected relatively more by local emission and deposition processes.

Nitrogen oxides $\left(\mathrm{NO}_{x}\right)$, carbon monoxide $(\mathrm{CO})$, sulfur dioxide $\left(\mathrm{SO}_{2}\right)$ and ozone $\left(\mathrm{O}_{3}\right)$ mixing ratio data were used in the analysis as ancillary data. The mixing ratios of $\mathrm{NO}_{x}$ were measured with a chemiluminescence technique (TEI 42C TL, Thermo Environmental Instruments, MA, USA), and $\mathrm{CO}$ was measured by an infrared light absorption analyzer (HORIBA APMA 360, Horiba, Japan). $\mathrm{SO}_{2}$ was measured with a fluorescence analyzer (TEI 43 BS, Thermo Environmental Instruments, MA, USA) and $\mathrm{O}_{3}$ by an ultraviolet light absorption technique (TEI 49, Thermo Environmental Instruments, MA, USA). $\mathrm{CO}, \mathrm{NO}_{x}, \mathrm{O}_{3}$, and $\mathrm{SO}_{2}$ were also measured at a height of $33 \mathrm{~m}$ except in 2010, when $\mathrm{CO}$ was measured at $16.8 \mathrm{~m}$.

\subsection{Trajectory analysis}

HYSPLIT 4 was used to calculate the air mass trajectories (Draxler and Hess, 1998). The arrival height of the calculated trajectories used for the analysis was 100 ma.g.l., thus representing air masses arriving at SMEAR II in the surface layer, in which the VOC VMR measurements were conducted in. Backward trajectories of $96 \mathrm{~h}$ (4 days) were calculated for every hour from 2006 to 2011 . In order to be able to remove the seasonal cycle from VOC VMRs, the monthly median values were interpolated for each hour of each day. The monthly median value was given to the day in the middle of the month and interpolation done for the periods between the mid-points of subsequent months using a Piecewise $\mathrm{Cu}$ bic Hermite Interpolating Polynomial (PCHIP) in order to achieve a smooth curve.

Each time a measured VOC VMR data were available at SMEAR II, they were associated with a trajectory arriving at the site at the same time. The path of the back trajectories was considered with a $1^{\circ} \times 1^{\circ}$ spatial resolution. The VMRs were assumed to remain constant during the whole transport time. The grid cells over which a trajectory traversed prior to its arrival at SMEAR II were associated with simultaneously measured VMR values. Finally, for each grid cell a single value for each VMR was obtained by calculating a mean of the VMRs from all the trajectories that have traversed it during the time period concerned (Stohl et al., 1995; Stohl and Seibert, 1998).

The differential source field was achieved by calculating first trajectory field using interpolated monthly median VMRs and then subtracting this from the actual source field. Thus, the trajectory maps indicate the typical VMR of a given 
compound when the air mass is arriving to the measurement site from the grid cell in question. For example, if the colour coding of a grid cell is $3 \mathrm{ppb}$ for methanol, this indicates that the VMR of methanol measured at SMEAR II, when the air mass is arriving through this grid cell, is $3 \mathrm{ppb}$ in average (see Figs. 3-5). The trajectory analysis was limited to the area between 50 and $75^{\circ} \mathrm{N}$ in latitude and 12 and $50^{\circ} \mathrm{E}$ in longitude. For reasons of statistical significance, at least 25 trajectories had to cross a grid cell in order for that grid cell to be accepted into the analysis, i.e. grid cells with less than 25 traverses were omitted from the analysis.

We selected 10 square shaped source areas for a further comparative study. The selection of source areas for further analysis was done subjectively, based on the trajectory maps and demographic information and information on industry and other possible sources in different geographical areas.

\subsection{Forest fire locations from satellite observations}

The forest fire location data were obtained from FIRMS (Fire Information Resource Managements System, 2014), which provides fire locations as observed globally by MODIS (Moderate Resolution Imaging Spectroradiometer). Data have been collected by NASA's Earth observing system (EOS) Terra and Aqua satellites. With these two satellites, global data coverage is achieved every 1-2 days.

\subsection{Unmix 6.0}

Source compositions and contributions were investigated with the multivariate receptor model EPA Unmix 6.0 (Norris et al., 2007), developed by Ronald Henry at the University of Southern California. A typical problem in multivariate receptor models is how to determine the optimal number of sources, the source fingerprints, and their contribution from the ambient air VOC measurement data alone. Normally, some additional constraints must be added in order to obtain unique solutions. In Unmix, this is obtained by requiring the composition and contribution of the sources to be be non-negative. In addition to this, Unmix searches for periods when the data indicate that the contribution of one of the sources is missing completely or its contribution is minor. The application of Unmix to VOC VMR data obtained by gas chromatographic methods at an urban site in Helsinki has been described by Hellén et al. (2003). According to the recommendations for the model, the regression of each of the species explained by the sources $\left(R^{2}\right)$ should be over 0.8 , while the signal-to-noise ratio should be over 2 . In this study, Unmix was applied for inorganic trace gas and VOC VMR data, except for monoterpenes that were excluded also from the source area trajectory analysis (see Sect. 3.5). Onehour median VMR values of inorganic trace gases and VOCs were used as input data to the model. Data were filtered by horizontal wind speed, excluding wind speeds below $1 \mathrm{~m} \mathrm{~s}^{-1}$ from the analysis. As a result $30 \%$ of data were excluded from the analysis. All of the results exceeded the recommended $R^{2}$ and signal-to-noise values, indicating that the receptor modelling results were applicable and valid.

For the Unmix analysis, VOC VMR and trace gas data were divided into three sectors according to the wind direction measured at SMEAR II. The division was made based on the findings of the VOC source fields as revealed by the trajectory analysis and described in Sect. 3.4. The three sectors were (1) north $\left(0-5\right.$ and $\left.300-360^{\circ}\right)$, (2) urbanized continental $\left(5-210^{\circ}\right)$, and $(3)$ urban and sea $\left(210-300^{\circ}\right)$.

\section{Results and discussion}

The VOC VMRs of most studied compounds have maxima in summer and minima in winter (Fig. 1), indicating the possible importance of biogenic and photochemical sources as well as other seasonal sources such as forest fires. Benzene, on the other hand, exhibited the opposite behaviour, likely due to a lack of significant biogenic sources and its shorter atmospheric lifetime in the summer. Of the other studied VOCs, methanol, acetone, and acetaldehyde as well as monoterpenes have biogenic sources in and around the measurement site (Rinne et al., 2007). Acetonitrile is emitted typically by biomass burning.

\subsection{Lifetimes of the observed VOCs}

To estimate the chemical lifetimes, defined as e-folding times, of VOCs, $\mathrm{OH}$ and $\mathrm{NO}_{3}$ radical concentrations were estimated based on the values presented by Hakola et al. (2003). The summertime $\mathrm{OH}$ concentration presented by Hakola et al. (2003) agreed well with the observations by Rinne et al. (2012), but the summertime $\mathrm{NO}_{3}$ concentration was at least twice as high as the observations. Thus, for this study, the annual cycle of $\mathrm{NO}_{3}$ as presented by Hakola et al. (2003) was scaled by dividing it by 2. Summerand wintertime median $\mathrm{O}_{3}$ concentrations were calculated from $\mathrm{O}_{3}$ measurements at SMEAR II. Photolysis values for summer- and wintertime were calculated following Hellén et al. (2004). Actinic flux values corresponding to the albedo for snow-covered forest in winter $($ albedo $=0.8)$ were used when photolysis values were calculated. The concentrations of oxidants and reaction rate coefficients used in calculations are presented in Tables 2 and 3.

The calculated atmospheric lifetimes of the VOCs studied here (methanol, acetonitrile, acetaldehyde, acetone, benzene, and toluene) for summer- and wintertime are presented in Table 4. Compared to the lifetimes of monoterpenes (about 1 day in winter and $1 \mathrm{~h}$ in summer), these lifetimes were much longer. For most compounds, the atmospheric lifetimes exceeded the duration of the back-trajectories used in this analysis. However, in summertime both toluene and acetaldehyde had lifetimes shorter than 4 days. Thus, for these compounds 
Table 2. Concentrations of hydroxyl $(\mathrm{OH})$, ozone $\left(\mathrm{O}_{3}\right)$, and nitrate radicals $\left(\mathrm{NO}_{3}\right)$ used in the lifetime calculations of the VOCs.

\begin{tabular}{|c|c|c|}
\hline Oxidants & winter [molecules $\mathrm{cm}^{-3}$ ] & summer $\left[\right.$ molecules $\mathrm{cm}^{-3}$ ] \\
\hline$[\mathrm{OH}]$ day & $5.5 \times 10^{4} \mathrm{a}$ & $1.5 \times 10^{6 \mathrm{a}}$ \\
\hline$\left[\mathrm{O}_{3}\right]$ day/night & $6.8 \times 10^{11} / 5.7 \times 10^{11}$ & $8.6 \times 10^{11} / 7.1 \times 10^{11}$ \\
\hline$\left[\mathrm{NO}_{3}\right]$ night & $1.2 \times 10^{7} \mathrm{~b}$ & $4.2 \times 10^{7 b}$ \\
\hline
\end{tabular}

${ }^{a}$ Hakola et al. (2003). ${ }^{\mathrm{b}}$ rescaled based on Hakola et al. (2003).

Table 3. Reaction rate coefficients $\left(k_{\mathrm{OH}}, k_{\mathrm{O}_{3}}, k_{\mathrm{NO}_{3}}\right)$ and photolysis rates for the measured VOCs.

\begin{tabular}{|c|c|c|c|c|c|}
\hline & $\begin{array}{l}k_{\mathrm{OH}} \\
{\left[\mathrm{cm}^{3} \text { molecules }^{-1} \mathrm{~s}^{-1}\right]}\end{array}$ & 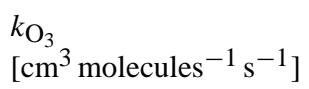 & $\begin{array}{l}k_{\mathrm{NO}_{3}} \\
{\left[\mathrm{~cm}^{3} \text { molecules }^{-1} \mathrm{~s}^{-1}\right]}\end{array}$ & $\begin{array}{l}k_{\text {photolysis }} \\
\text { in winter }\left[\mathrm{s}^{-1}\right]\end{array}$ & $\begin{array}{l}k_{\text {photolysis }} \\
\text { in summer }\left[\mathrm{s}^{-1}\right]\end{array}$ \\
\hline Methanol & $9.00 \times 10^{-13 a}$ & & $2.42 \times 10^{-16 \mathrm{~d}}$ & & \\
\hline Acetaldehyde & $1.50 \times 10^{-12 \mathrm{a}}$ & & $2.72 \times 10^{-15 \mathrm{e}}$ & $1.50 \times 10^{-6 \mathrm{f}}$ & $3.27 \times 10^{-6 f}$ \\
\hline Acetone & $1.80 \times 10^{-13 a}$ & & $3.00 \times 10^{-17 \mathrm{e}}$ & $2.32 \times 10^{-7 f}$ & $4.85 \times 10^{-7 f}$ \\
\hline Benzene & $1.19 \times 10^{-12 \mathrm{a}}$ & $1.70 \times 10^{-22 c}$ & $3.00 \times 10^{-17 d}$ & & \\
\hline Toluene & $5.60 \times 10^{-12 a}$ & $4.10 \times 10^{-22 c}$ & $6.79 \times 10^{-17 d}$ & & \\
\hline Monoterpenes & $7.50 \times 10^{-11 b}$ & $1.4 \times 10^{-17 b}$ & $7.06 \times 10^{-12 b}$ & & \\
\hline
\end{tabular}

Rate constants $\left(k_{\mathrm{OH}}, k_{\mathrm{O}_{3}}\right.$, and $k_{\mathrm{NO}_{3}}$ ) used in calculations in Table 4: ${ }^{\mathrm{a}}$ iupac preferred, ${ }^{\mathrm{b}}$ Monoterpenes' rate constants $k_{\mathrm{OH}}, k_{\mathrm{O}_{3}}$ and $k_{\mathrm{NO}_{3}}$ were calculated as weighted averages of individual monoterpenes typical in SMEAR II (Hakola et al., 2003), individual $k$ values (Atkinson, 1994), ${ }^{c}$ Atkinson, 1994,

${ }^{\mathrm{d}}$ http://kinetics.nist.gov/kinetics/Search.jsp, last access: 17 January 2013, ${ }^{\mathrm{e}}$ Rinne et al. (2007), ${ }^{\mathrm{f}}$ Calculated similar to Hellén et al. (2004).

the results of the 4-day backward trajectory analysis should be interpreted with caution.

In the following first the trajectories from the two major forest events are discussed. Second, the general features of the trajectory fields over the whole measurement period are presented. Third, the features and seasonal differences of sources in a set of selected areas are discussed.

\subsection{Forest fire episodes in Russia in the summers of 2006 and 2010}

During the measurement periods two particularly active forest fire episodes with several fire hotspots occurred in Russia, one in summer 2006 and the other in summer 2010. They also influenced air quality in Finland (Leino et al., 2014). These fires provide temporally and spatially well-defined sources of trace gases that can be used to evaluate the ability of the trajectory analysis to identify such source areas.

Biomass burning has previously been observed to be a source of VOCs in several field and laboratory studies (e.g. Crutzen and Andreae, 1990; Holzinger et al., 1999; de Gouw et al., 2006; Virkkula et al., 2014). Acetonitrile has commonly been used as a marker compound for emissions from biomass burning (de Gouw et al., 2003, 2006; Holzinger et al., 1999). The oxygenated VOCs (OVOCs) and aromatic VOCs (benzene and toluene) have also been linked to biomass burning in different studies (Koppmann and Wildt, 2007; de Gouw et al., 2006).

Forest fires, which were observed during these measurements, occurred in the year 2006 in the Vyborg area near the Finnish-Russian border and in year 2010 in the Moscow area (Fig. 2). The sum of all observed fires during the two episodes are shown in Fig. 2. Any particular fire location shown in the map has not necessarily been burning the whole summer. During the summer of 2010 an unusually high temperature anomaly was observed in eastern Europe (Twardosz and Kossowska-Cezak, 2013). These circumstances can be favourable for the ignition and development of major forest fires.

In the summer of 2006 the largest fires occurred south of Moscow and in Belarus. There were also fires in Karelia, in Vyborg area near St. Petersburg and the Finnish-Russian border. The first forest fire episode occurring within the timeframe of this study was in the period of 4-31 August 2006. The trajectory analysis showed the high VOC mixing ratios observed at SMEAR II during this period to have originated from the forest fire area (Fig. 3). Unfortunately, acetonitrile was not measured during this period. Anttila et al. (2008) also observed elevated amounts of particulate matter mass $\left(\mathrm{PM}_{10}\right.$, $\mathrm{PM}_{2.5}$ ) and higher polycyclic aromatic hydrocarbon (PAH) concentrations during this period at Virolahti, located on the Finnish southern coast near the Finnish-Russian border.

During the summer of 2010 a large number of forest fires were located in north-western Russia. The second forest fire episode within the time frame of this study occurred in 20 July-31 August 2010. During this period, acetonitrile data were also measured at SMEAR II. By comparing the forest fire locations (Fig. 2) and acetonitrile's mean VMR field from trajectory analysis, one can see that acetonitrile originates from the general direction of the maximum burning 
Table 4. Total atmospheric lifetimes ( $e$-folding times) of the VOCs studied, daytime and night-time in summer and winter. Daytime values are the sums of lifetimes calculated towards $\mathrm{O}_{3}, \mathrm{OH}$ and photolysis. Night-time values were calculated towards $\mathrm{O}_{3}$ and $\mathrm{NO}_{3}$.

\begin{tabular}{lllll}
\hline VOC & $\begin{array}{l}\text { Total lifetimes on } \\
\text { a winter day }\end{array}$ & $\begin{array}{l}\text { Total lifetimes on } \\
\text { a winter night }\end{array}$ & $\begin{array}{l}\text { total lifetimes on } \\
\text { a summer day }\end{array}$ & $\begin{array}{l}\text { Total lifetimes on } \\
\text { a summer night }\end{array}$ \\
\hline Methanol & 230 day & $1 \mathrm{yr}$ & 9 day & 110 day \\
Acetonitrile & $29 \mathrm{yr}$ & $5300 \mathrm{yr}$ & $1 \mathrm{yr}$ & $1500 \mathrm{yr}$ \\
Acetaldehyde & 5 day & $1 \mathrm{yr}$ & 1 day & $100 \mathrm{day}$ \\
Acetone & 48 day & $88 \mathrm{yr}$ & 15 day & $25 \mathrm{yr}$ \\
Benzene & 180 day & $69 \mathrm{yr}$ & 6 day & $27 \mathrm{yr}$ \\
Toluene & 38 day & $29 \mathrm{yr}$ & 1 day & $11 \mathrm{yr}$ \\
Monoterpenes & 1 day & $3 \mathrm{~h}$ & $1 \mathrm{~h}$ & $0.9 \mathrm{~h}$ \\
\hline
\end{tabular}
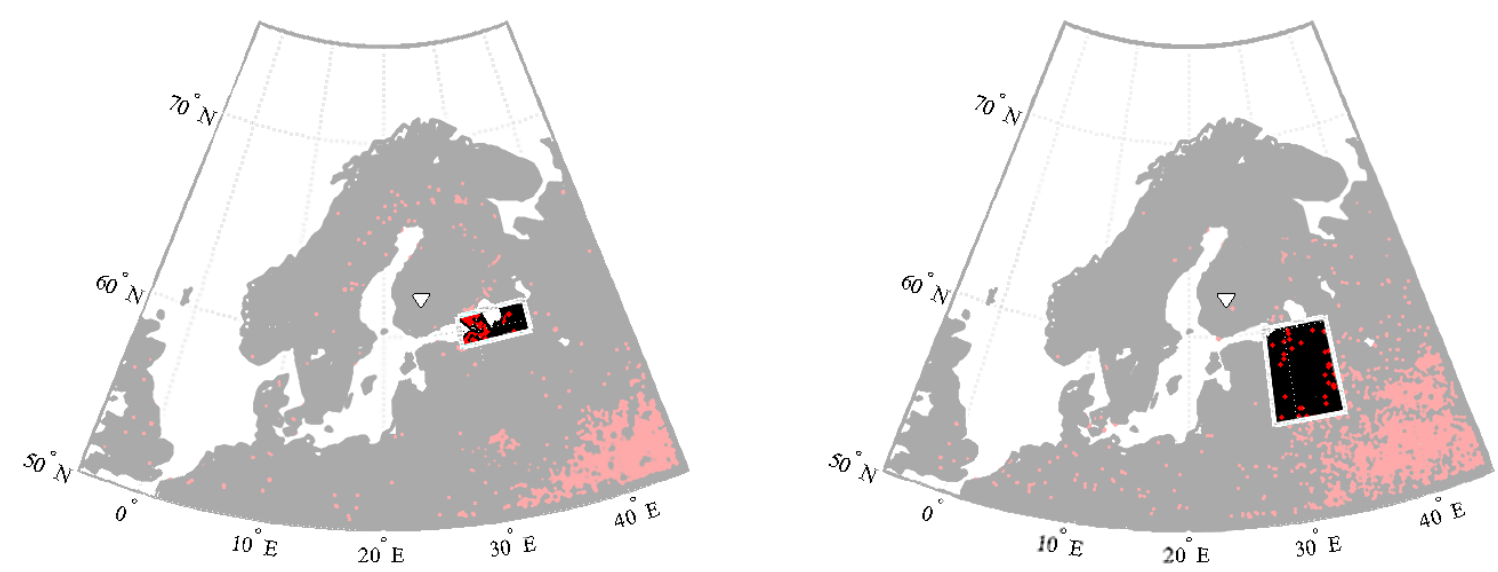

Figure 2. Map of forest fire locations during the forest fire episodes of the summers of 2006 (left) and 2010 (right). In 2006 , the forest fire event occurred during 4-31 August and in 2010 during 20 July to 31 August. These maps depict the sum of all observed fire spots during the burning periods, each being shown by a dot. Data of forest fire locations are taken from the Fire Information Resource Managements System (FIRMS, 2014). The SMEAR II site is marked by a white triangle in the map.

area (Fig. 4). All the other VOCs and trace gases studied also had similar source area distributions.

For a comparison of VOC VMRs during fires and without fire, the mean VMR values of methanol, acetonitrile, benzene, $\mathrm{SO}_{2}$ and $\mathrm{CO}$ were calculated for periods both before and during the forest fire episodes in both years (Table 5). In 2006 the period from 1 to 31 July 2006 was selected to represent the situation before the forest fires. In, 2010 the period from 25 June to 15 July 2010 was used for the same purpose. In both cases concentrations were calculated using data chosen by trajectories which had traversed the fire areas. In this study, the forest fire areas were selected to be $\left(58-62^{\circ} \mathrm{N}, 27-\right.$ $\left.36^{\circ} \mathrm{E}\right)$ (area 1) in 2006 and $\left(56-61^{\circ} \mathrm{N}, 28-34^{\circ} \mathrm{E}\right)$ (area 2) in 2010.

Many of the VMRs of VOCs were $50-100 \%$ higher when the air mass was transported from active forest fire than before it. For example, before the forest fire episode in year 2010, the VMR of acetonitrile was $0.06 \mathrm{ppb}_{\mathrm{v}}$, while during the episode it was $0.13 \mathrm{ppb}_{\mathrm{v}}$. Benzene also had elevated VMR levels in air masses that had travelled over the forest fires. In 2006, benzene's VMR before the forest fires was
$0.08 \mathrm{ppb}_{\mathrm{v}}$ and during the episode $0.17 \mathrm{ppb}_{\mathrm{v}}$; in 2010 the values were 0.05 and $0.09 \mathrm{ppb}_{\mathrm{v}}$, respectively. These compounds have earlier been observed to be emitted from biomass burning (Holzinger et al., 1999; Simpson et al., 2011; Virkkula et al., 2014). Elevated CO concentrations were also observed in air masses associated with forest fires while the difference in NOx was not significant. The mean VMRs of methanol did not increase during the fire episodes, which indicates that methanol at SMEAR II has other dominant sources, such as biogenic emissions from vegetation. $\mathrm{SO}_{2}$ is usually linked to fossil fuel combustion processes rather than biomass burning (Seinfeld and Pandis, 1998). In this study the change in $\mathrm{SO}_{2}$ concentration was to different directions for the 2 years, indicating other processes besides forest fires affecting the concentrations as well.

\subsection{General features of source areas}

The mean trajectory fields of the VOCs studied here (methanol, acetonitrile, acetaldehyde, acetone, benzene, and toluene), as well as those of $\mathrm{CO}, \mathrm{NO}_{x}$ and $\mathrm{SO}_{2}$ from the year 2006 to the year 2011 are presented in Fig. 5. These include 

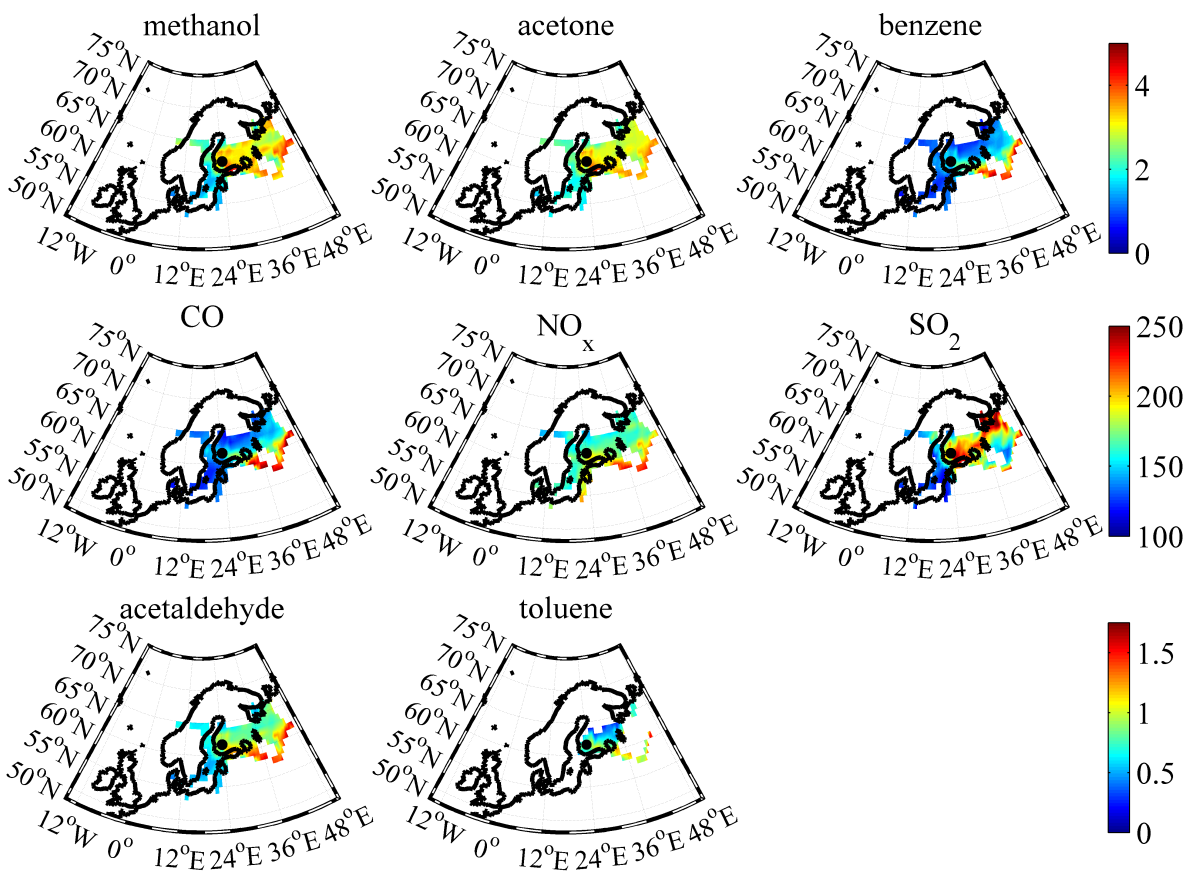

Figure 3. Mean trajectory fields for selected VOCs and trace gases $\left(\mathrm{ppb}_{\mathrm{V}}\right.$ ) during the forest fires in summer 2006. VMR scales are presented on the right, with the scale for each compound being multiplied in the case of each compound by the indicated factor 10,100 or 1000 if needed. Topmost row: methanol, acetone, and benzene (benzene multiplied by 10). Middle row: $\mathrm{CO}, \mathrm{NO}_{x}\left(\mathrm{NO}_{x}\right.$ multiplied by 10), and $\mathrm{SO}_{2}$ ( $\mathrm{SO}_{2}$ multiplied by 100). Bottom row: acetaldehyde and toluene (toluene multiplied by 10). The SMEAR II site is marked by a dot in the map.
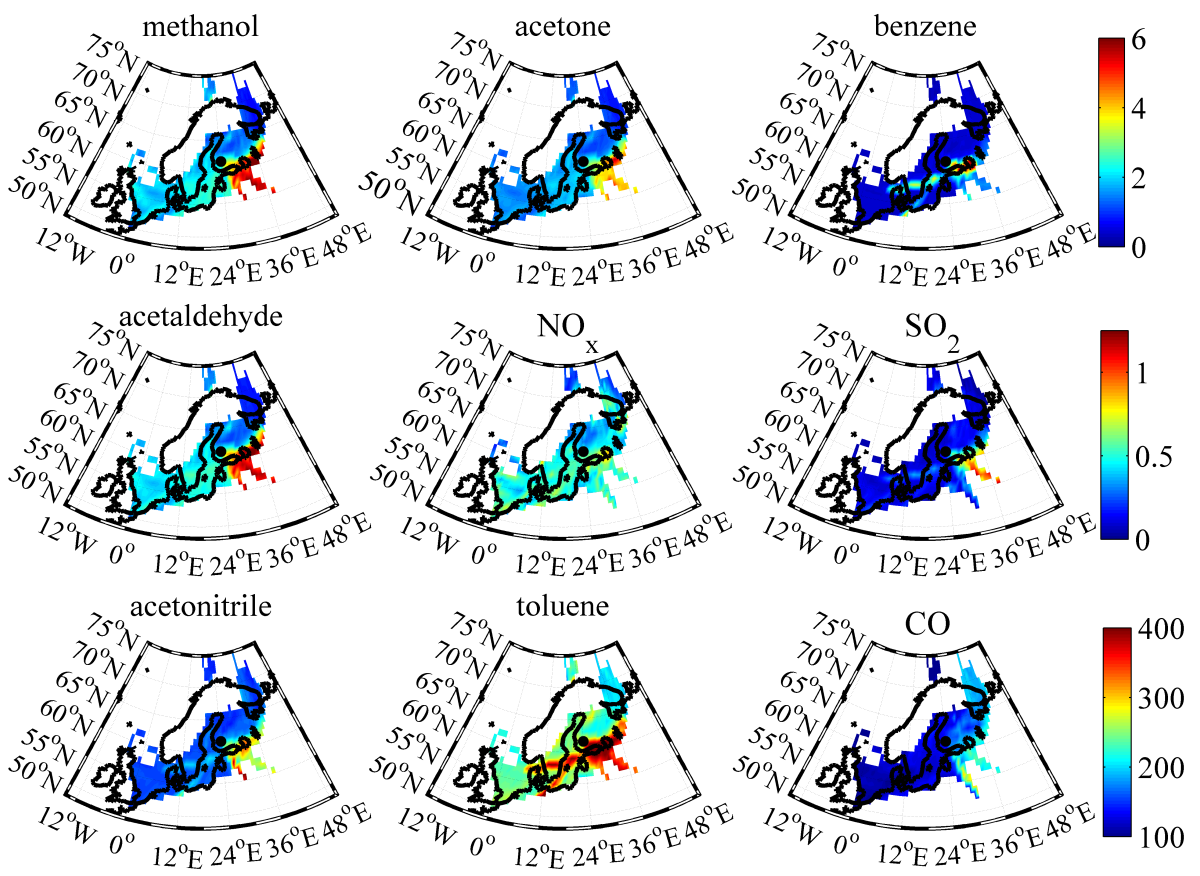

Figure 4. Mean trajectory fields for selected VOCs and trace gases $\left(\mathrm{ppb}_{\mathrm{V}}\right)$ during the forest fires in summer 2010. VMR scales are presented on the right, with the scale for each compound being further multiplied in the case of each compound by the indicated factor 10,100 or 1000 if needed. Topmost row: methanol, acetone, and benzene (benzene multiplied by 10). Middle row: acetaldehyde, $\mathrm{NO}_{x}$, and $\mathrm{SO}_{2}$. $\mathrm{Bottom}$ row: acetonitrile (acetonitrile multiplied by 1000), toluene (toluene multiplied by 1000), and CO. The SMEAR II site is marked by a dot in the map. 
Table 5. Mean VMRs of studied trace gases $\left(\mathrm{ppb}_{\mathrm{v}}\right)$ and standard deviations (SDs) before and during the forest fire episodes in 2006 and 2010. The VMRs of the compounds were calculated from VMR data which were selected using trajectories from the burning areas. Area 1 is $58-62^{\circ} \mathrm{N}, 27-36^{\circ} \mathrm{E}$ in 2006 and area 2 is $56-61^{\circ} \mathrm{N}, 28-34^{\circ} \mathrm{E}$ in 2010 . Asterisk indicates when VMR of a trace gas differs significantly from pre-fire VMR (two-sided $t$ test).

\begin{tabular}{lllllllll}
\hline Compounds & $\begin{array}{l}\text { In 2006 } \\
\text { before } \\
\text { episode }\end{array}$ & SD & $\begin{array}{l}\text { In 2006 } \\
\text { during } \\
\text { episode }\end{array}$ & SD & $\begin{array}{l}\text { In 2010 } \\
\text { before } \\
\text { episode }\end{array}$ & SD & $\begin{array}{l}\text { In 2010 } \\
\text { during } \\
\text { episode }\end{array}$ & SD \\
\hline $\begin{array}{l}\text { Methanol } \\
\text { Acetonitrile }\end{array}$ & 4.9 & 0.78 & $3.2^{*}$ & 1.21 & 3.7 & 0.75 & 3.7 & 2.10 \\
Acetaldehyde & 0.86 & 0.31 & 0.94 & 0.41 & 0.55 & 0.09 & $0.76^{*}$ & 0.40 \\
Acetone & 3.0 & 0.40 & 3.0 & 0.88 & 2.0 & 0.32 & $2.8^{*}$ & 1.44 \\
Benzene & 0.08 & 0.03 & $0.17^{*}$ & 0.13 & 0.05 & 0.03 & $0.09^{*}$ & 0.06 \\
Toluene & 0.05 & 0.03 & $0.09^{*}$ & 0.07 & 0.21 & 0.09 & $0.28^{*}$ & 0.11 \\
Sulfur dioxide & 0.23 & 0.14 & $0.16^{*}$ & 0.15 & 0.20 & 0.12 & $0.35^{*}$ & 0.42 \\
Nitrogen oxides & 1.3 & 0.56 & 1.3 & 0.51 & 0.60 & 0.47 & 0.47 & 0.28 \\
Carbon monoxide & 130 & 5 & $150^{*}$ & 49 & 110 & 9 & $150^{*}$ & 45 \\
\hline
\end{tabular}
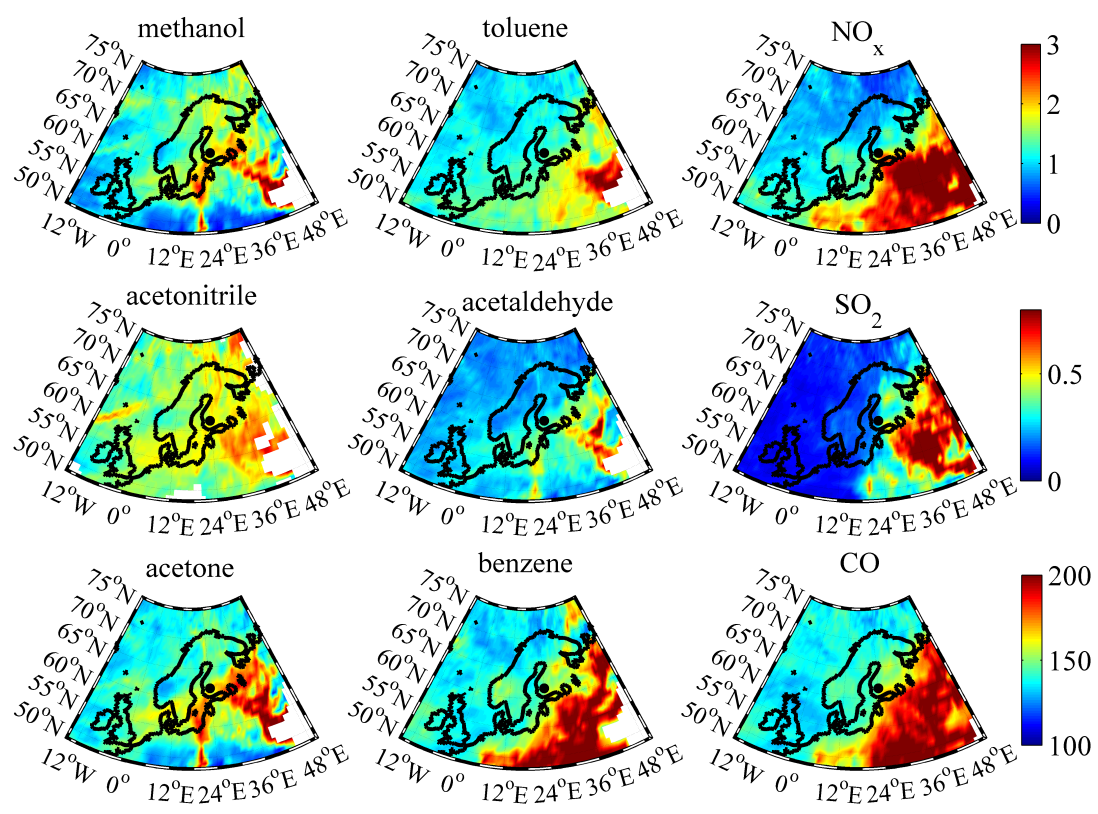

Figure 5. Mean trajectory fields (2006-2011) of selected VOCs and trace gases $\left(\mathrm{ppb}_{\mathrm{v}}\right)$. VMR scales are presented on the right, with the scale for each compound being further multiplied in the case of each compound by the indicated factor 10, 100 or 1000 if needed. Topmost row: methanol, toluene (multiplied by 10) and $\mathrm{NO}_{x}$. Middle row: acetonitrile (multiplied by 10), acetaldehyde, $\mathrm{SO}_{2}$. Bottom row: acetone (multiplied by 100), benzene (multiplied by 1000) and CO. The SMEAR II site is marked by a dot in the maps.

the forest fire episodes described above, as well as other more dispersed fires. From this figure it can be seen that methanol, acetone, and acetaldehyde had very similar source areas. There was very good correlation between methanol and acetone $(r=0.86, p<0.05)$. Methanol and acetaldehyde were also correlated with each other $(r=0.66, p<0.05)$. On the other hand, the source areas of benzene, toluene, $\mathrm{CO}$, and $\mathrm{NO}_{x}$ were similar to each other. Acetonitrile had similarities with both methanol and benzene, correlating better with the methanol group than with the benzene group. Both are released in incomplete burning processes (Sect. 3.1). The cor- relation matrix, Pearson's correlation coefficients and $p$ values between all compounds are presented in Fig. A1 in the appendix. All $p$ values were below 0.05 , except those for the correlations between methanol and $\mathrm{NO}_{x}$ and acetonitrile and acetaldehyde, which were statistically insignificant. Anthropogenically influenced source areas (benzene, toluene, $\left.\mathrm{NO}_{x}, \mathrm{CO}\right)$ were observed in the northern part of continental Europe and eastern Europe, Fennoscandia, western Russia, and marine and coastal areas (Baltic Sea, Barents Sea, White Sea, Norwegian Sea and North Sea) (Fig. 5). Northern Fennoscandia seemed to be quite free of anthropogenic 
sources of VOCs. $\mathrm{NO}_{x}, \mathrm{CO}$ and $\mathrm{SO}_{2}$ concentrations were also low in air masses arriving from the north. With the exception of methanol and acetonitrile, the VOCs did not have source areas in the northern area. The occurrence of forest fires in Russia is visible in the mean trajectory fields of all compounds. In addition to biomass burning, some small local emissions, e.g. from traffic, wood combustion and biogenic emissions may also have had an effect on the results.

The source areas of $\mathrm{SO}_{2}$ were similar to those of $\mathrm{NO}_{x}$ and $\mathrm{CO}$. The main source areas of $\mathrm{SO}_{2}$ were western Russia, northern Poland and Kaliningrad, while $\mathrm{NO}_{x}$ and $\mathrm{CO}$ had additional source areas in western Europe. Riuttanen et al. (2013) found a similar sharp distinction in $\mathrm{SO}_{2}$ concentrations between air masses arriving from eastern and western Europe. The study also found that air masses coming from central Europe were exposed to more rain, and thus were subject to the wet removal of $\mathrm{SO}_{2}$. They speculated that this may have been one reason why $\mathrm{SO}_{2}$ source areas in central Europe were not separable in the trajectory fields. However, in this study we found that the also water-soluble methanol and $\mathrm{NO}_{x}$ were not totally washed out during transport from central Europe, as there were visible source areas for methanol in the North Sea, Skagerrak and the northern Germany areas, and for $\mathrm{NO}_{x}$ in northern continental Europe (Fig. 5). Thus we propose that wet deposition does not fully explain the absence of $\mathrm{SO}_{2}$ in the air masses arriving from western Europe, as interpreted by Riuttanen et al. (2013), but that the observed difference in $\mathrm{SO}_{2}$ is probably due to more rigorous emission regulations in the western part of Europe than the eastern part. This interpretation is supported by Vestreng et al. (2007), who observed a significant difference in the reduction of emissions of $\mathrm{SO}_{2}$ between western and eastern Europe during years 1980-2004.

\subsection{Source areas and their seasonal difference}

In order to study the possible seasonal changes in the VOC source areas, these were determined separately for the summer (June-August) and the winter (December-February) periods. Data during the short forest fire episodes during summers 2006 and 2010 were removed prior to this analysis so that they would not mask the differences due to other seasonally altering sources. Although there was some inter-annual variation in the observed VMRs of VOCs, no clear trends of VMRs were observed during the whole measurement period (Fig. 1).

The climatic conditions in summers during the measurement period were different from each other, which may have led to differences in biogenic source strength, source area distributions, and VOC VMRs. For example the median temperature between summers in Finland at Hyytiälä were observed to vary from 12.9 to $17^{\circ} \mathrm{C}$, which may have an effect on the biogenic emissions of VOCs such as methanol, acetone, and monoterpenes (Fig. 1).
The source areas of many/most VOCs are broadly similar in summer and winter-time (Supplement) even though in winter the continental air masses are associated with colder than average temperatures and in summer with warmer. This indicates that the temperature is not the main driver of the spatial patterns revealed by the source area analysis.

Detecting the interannual differences in source areas was problematic because, e.g. in summer 2006 air masses arrived from western Russia, but there were no arrivals from central Europe. Summers 2006 and 2010 were both influenced by continental climate, and air masses arrived from western Russia (area 1) bringing warm air as well as elevated VOC VMRs from the coinciding forest fires.

The fact that there is no significant trend in monoterpene VMRs indicates that it is unlikely for local biogenic activity to have a trend affecting the VOC VMRs. As the monoterpenes have atmospheric lifetime in the range of hours to days thus corresponding to the transport from local source areas, they would be most sensitive to show such an effect.

Additionally, in the case of monoterpenes' VMRs the change of the sampling location may hinder an observation of a trend over the whole measurement period, as monoterpenes have a short life time ( $1 \mathrm{~h}$; Table 4$)$.

The source areas of the VOCs also varied slightly between years due to variations in the VOC VMRs, deposition and the prevailing paths of arriving air masses. Despite these differences, all five summers (2006-2008, 2010-2011) and two winters (2006-2007 and 2008-2009) were combined in this study to get as good an areal trajectory data coverage as possible for summers and winters separately. Summer 2009 was not included in the trajectory analysis because VOC VMR data were only available for 18 days.

For the evaluation of the VOC source areas, 10 rectangular areas were selected for separate analysis during both main seasons (summer, winter) (Fig. 6). These areas differ from each other in having, e.g. different industrial structures and population densities.

The 10 selected areas were as follows.

1. Western Russia $\left(54-61^{\circ} \mathrm{N}, 29-40^{\circ} \mathrm{E}\right)$ - In this area there are two densely populated cities, Moscow and St. Petersburg, and also harbours on the Baltic Sea. The area includes many different industries as described in detail in Table A1 in the appendix.

2. Northern Poland, Kaliningrad and Baltic countries (Estonia, Latvia and Lithuania) $\left(53-59^{\circ} \mathrm{N}, 18-28^{\circ} \mathrm{E}\right)-$ This area includes the port of Gdańsk, which is one of the important harbours in the Baltic Sea. Similarly to the Western Russia there is also a lot of industry in this area.

3. Karelia and the White Sea $\left(63-66^{\circ} \mathrm{N}, 31-40^{\circ} \mathrm{E}\right)-$ This area is a significant Russian industrial area, including also large forests and the coastal areas of White Sea. 


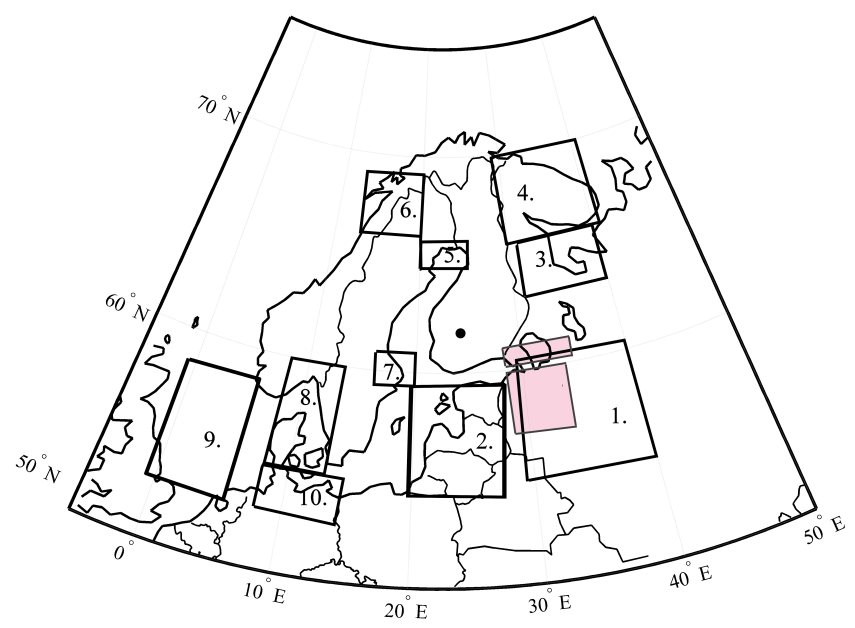

Figure 6. Main source areas of VOCs: (1) western Russia, (2) northern Poland, Kaliningrad and Baltic countries, (3) Karelia and the White Sea, (4) Kola Peninsula and Barents Sea, (5) Bay of Bothnia, (6) Coast of Norwegian Sea and northern Sweden, (7) Stockholm area, (8) Skagerrak, (9) North Sea and coastal areas, (10) northern Germany. Two forest fire source areas, limited in time, are marked by pink boxes. These are treated separately for the episodes (see Table 5). The SMEAR II site is marked by a dot in the map.

Compared to the Western Russian source area, the Karelia and White Sea area is more sparsely populated.

4. The Kola Peninsula and Barents Sea $\left(66-70^{\circ}\right.$ N, $29-$ $42^{\circ} \mathrm{E}$ ) - This area is rich in minerals and is therefore an important Russian industrial area. Around the Barents Sea there is an active petroleum industry (Austvik, 2007) with several oil drilling sites and oil tankers present on the Norwegian and Russian coasts.

9. Europe's important offshore oil and gas fields are situated in the North Sea and coastal areas $\left(52-58^{\circ} \mathrm{N}\right.$, $-1-6^{\circ}$ E) - Norway, Denmark, Germany, the Netherlands and the UK are involved in oil production in the North Sea (EIA, International Energy Outlook, 2014). The coastal areas of the North Sea are also very densely populated.

10. Northern Germany $\left(52-54^{\circ} \mathrm{N}, 8-15^{\circ} \mathrm{E}\right)-$ This is one of Germany's main industrial areas, with several important harbours such as Hamburg, Lübeck and Rostock.

To evaluate the influence of the selected source areas for the measured VMR VOCs, during summer and winter, trajectory fields for the difference between the measured VMRs and the median seasonal cycle, defined as linearly interpolated values on monthly medians, were calculated for each compound. This is called differential source field, with the seasonal trend on VMRs removed from it. The average values of the differential source field for the ten areas listed above are presented in Fig. 7. Acetonitrile was included in the source area analysis in summer only, when forest fires occurred.
In urban areas VOCs originate mostly from traffic, but are also emitted from other combustion processes, evaporation of fuels, and various industrial processes (Reimann and Lewis, 2007; Hellén et al., 2006). The 10 areas investigated here were mainly located in heavily industrialized areas and/or areas with high population density. The strongest source areas for all the VOCs studied were located in eastern Europe including western Russia (1), northern Poland, Kaliningrad and the Baltic countries (2), Karelia and the White Sea (3). In these areas, the calculated differential source is clearly positive for nearly all compounds (Fig. 7). The negative differential source of many compounds in, e.g. area 6 indicates that their VMRs are below the seasonal median in air masses arriving from this area.In addition to these source areas, which are common to most of the studied compounds, certain compounds have specific source areas of their own. Methanol is an abundant VOC in the atmosphere having many different sources, both biogenic and anthropogenic (Jacob et al., 2005). From Fig. 7 it can be seen that nearly all of the selected areas are sources of methanol especially in the summer. eastern European source areas (1-3) were observed to generally be large emitters of OVOCs (methanol, acetaldehyde, and acetone). This is in line with earlier observations by Hellén et al. (2004), who reported eastern Europe to be an important emitter of carbonyls. In addition to these source areas, acetone and acetaldehyde also arrived from the areas of Stockholm, the Skagerrak, the North Sea and the coastal areas and northern Germany: all of these areas have emissions from traffic and solvent use related, to various industrial activities. The oxidation of hydrocarbons and the primary biogenic emission are known to be the major global source of acetaldehyde (Singh et al., 2004); these sources have not, however, been taken into account in this study. Acetaldehyde also has a relatively short lifetime (1 day) during summer. These factors can add some uncertainty to this analysis of acetaldehyde. Benzene was also found to have sources in the Kola Peninsula area, most likely connected with the petrochemical industry and mining. However, the North Sea area with its active petrochemical industry did not appear as a distinguishable source area for aromatic VOCs in this study.

As seen earlier, when comparing the VMRs of VOCs before and during the forest fires, the mixing ratios at SMEAR II for benzene and acetonitrile were found to be significantly elevated during these episodes (Table 5, Fig. 7). The forest fires are a strong sources of most of the VOCs studied here. In 2010 acetonitrile's VMR difference from the background values was $0.07 \mathrm{ppb}_{\mathrm{v}}$. In other source areas, acetonitrile's differential source was near zero (Fig. 7).

The areas with strongest differential source indicated anthropogenic sources. However, the vast boreal forest zone in northern Europe is an important emitter of biogenic VOCs (BVOCs). Most BVOCS emitted from boreal forests are short-lived terpenoids, whose high atmospheric reactivity keeps their concentrations relatively low compared to those of, e.g. OVOCs, with longer atmospheric lifetimes (Hakola 


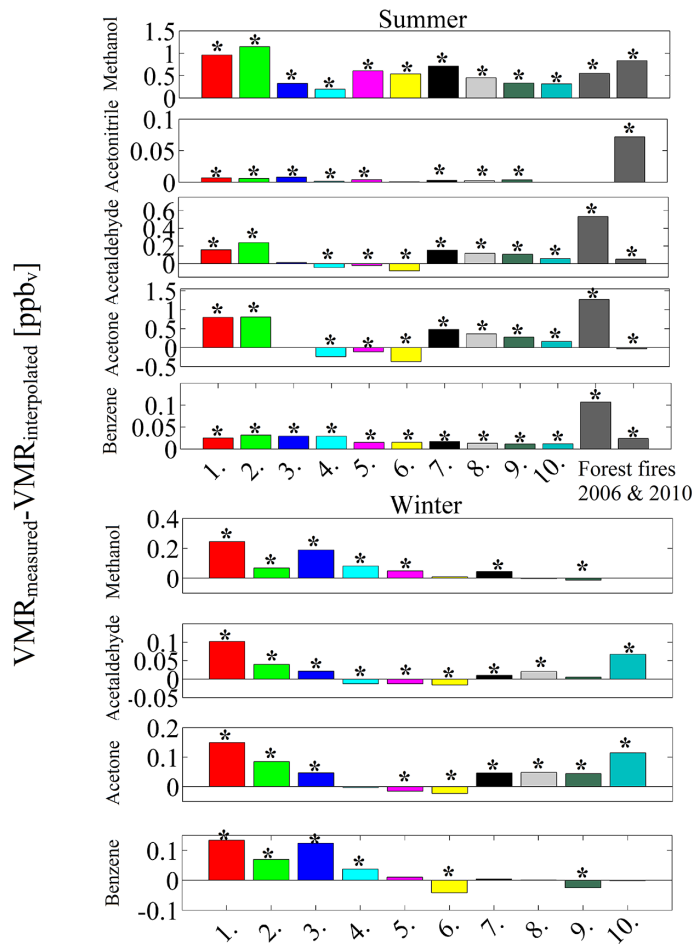

1) Western Russia

2) Northern Poland,

Kaliningrad and

Baltic countries

3) Karelia and the White Sea

4) Kola Peninsula and

Barents Sea

5) Bay of Bothnia

6) Coast of Norwegian Sea and

Northern Sweden

7) Stockholm area

8) Skagerrak

9) North Sea and

coastal areas

10) Northern Germany

Figure 7. Differential source fields $\mathrm{VMR}_{\text {measured }}-\mathrm{VMR}_{\text {interpolated }}\left(\mathrm{ppb}_{\mathrm{V}}\right)$ Hourly VMR values of source areas interpolated from monthly medians were subtracted from directly measured hourly values of source areas during summer (upper panel) and during winter (lower panel) for methanol ( $m$ 33), (acetonitrile $(m 42)$, in summer only), acetaldehyde $(m 45)$, acetone $(m 59)$ and benzene $(m$ 79). Forest fire data were removed from summer data and analyzed separately. Asterisk indicates when differential VMR fields of a trace gases differ significantly from zero (two-sided $t$ test).

et al., 2003). In this study, the forest regions were not identifiable as well-defined source areas; however, they probably did contribute to background levels. During summer there were minor source areas in the Baltic Sea, where there should be no anthropogenic sources. These interesting source areas could be due to the production of VOCs by e.g. algae or cyanobacteria. However, the VMR levels of VOCs originating from algae are low compared to anthropogenic sources (Kansal et al., 2009). With the current data and analysis it is not possible to identify the source of these marine emissions. In the future their origin could be clarified by using shorter trajectories and making measurements near the Baltic Sea, or by collecting samples from over the Baltic Sea.

\subsection{Low concentrations from the north, urban influences from continents and seas}

VOC source profiles were analyzed with the Unmix 6.0 receptor Model for different wind sectors. In all sectors three distinctive sources were identified: (1) a source containing mainly $\mathrm{SO}_{2}$, and thus this was named the $\mathrm{SO}_{2}$ source, (2) a source containing toluene, benzene, $\mathrm{NO}_{x}$, and $\mathrm{CO}$. These compounds are typical of anthropogenic emissions, and thus the source was named the anthropogenic source, (3) a source containing oxygenated VOCs (OVOCs, methanol, acetone,

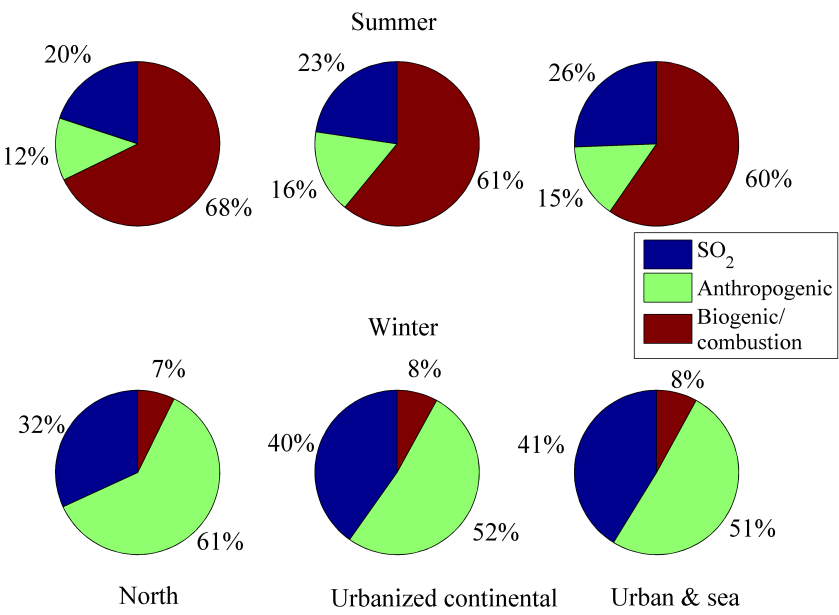

Figure 8. Pie charts of mean values of sources in each sector during summer (June-August) (topmost row) and during winter (December-February) (bottom row). The north sector includes data from direction $0-5$ and $300-360^{\circ}$, urbanized continental from 5$210^{\circ}$ and urban and sea sector from $210-300^{\circ}$.

and acetaldehyde), acetonitrile, and a portion of CO. This source was related to biomass burning and other biogenic emissions and was named as a biogenic/combustion source. 

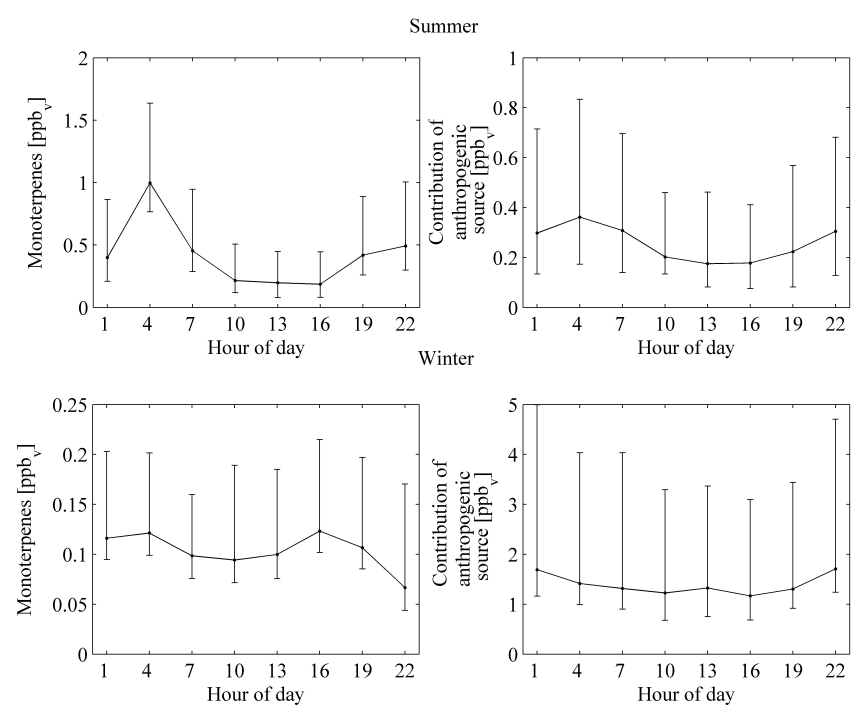

Figure 9. Diurnal cycles of monoterpenes (left) and the diurnal cycle of the anthropogenic source's contribution (right) in summer (top row) and in winter (bottom row) are presented as mean values and 20 to 80 percentiles. Data in all figures are from the urbanized continental sector.

The mean contributions of these sources to VMRs with wind from different sectors were similar within the seasons but there was a major difference between seasons. The contribution of the anthropogenic source was dominant in winter and the biogenic/combustion source in summer (Fig. 8). The dominance of the biogenic/combustion source in summer can be attributed to two processes. First, the biogenic/combustion source included acetonitrile, and high mixing ratios of acetonitrile were observed during forest fire episodes in summer. Second, this source included OVOCs which also have biogenic sources and thus higher VMRs during summer (Fig. 1). Biogenic emissions of the monoterpenes measured at SMEAR II are dominant in the summer, and due to relatively short lifetime their VMRs are dominated by the local sources. However, from the time series of monoterpenes we can see that there are occasionally notably high VMR peaks, which are known to have an anthropogenic origin (Liao et al., 2011) (Fig. 1).

In Fig. 9 median diurnal cycle of the anthropogenic VOC source is compared to that of the monoterpenes. The data are from the urbanized continental sector. Monoterpenes, representing local biogenic sources, had a considerable diurnal variation during the summer, with higher mixing ratios at night, and no variation in winter, as also observed in previous studies in similar ecosystems (Hakola et al., 2000; Rinne et al., 2005). This is due to the diurnal cycle in the surface layer mixing and the night-time emissions of monoterpenes from coniferous trees. The aromatic VOCs have shorter summertime lifetimes as compared to winter, leading to lower anthropogenic source levels in summer. The contribution of the anthropogenic source in winter was about three times higher in all sectors than in summer. Both summertime and wintertime diurnal cycles of the anthropogenic source showed a maximum at night, possibly due to lower night-time mixing in the boundary layer. This diurnal cycle is similar to that of monoterpenes and indicates that there is local influence on the anthropogenic source.

Histograms of the source contributions, together with their mean, median, and maximum values both in summer and in winter, are presented in Figs. 10 and 11. Many of these distributions are skewed, having a tail of high contribution values. Thus the mean and median values of these source contributions may have large differences. The skewness of the source distributions also indicates that the simplest statistical parameters, such as mean and median, may not adequately describe the distribution of the sources or their contribution to the local atmospheric mixing ratios of these compounds. There were considerable differences between the source distributions from different wind direction sectors. Wind arrivals are distributed in all directions (Lappalainen et al., 2009). Air masses arriving from the northern sector had in general lower mean source contributions than air masses from the urbanized continental and the urban and sea sectors. Particularly in the summer there was a tail of high contributions in the urbanized continental and the urban and sea sectors for anthropogenic source (maximum values were 17.2/4.7) and biogenic/combustion source $(9.8 / 6.1)$, as compared to the north sector whose maximum contributions were 1.6 and 4.9 for the anthropogenic and biogenic/combustion sources, respectively. However, the median values were much closer to each other. This indicates that air masses from the north were had fewer pollution events with high VOC VMRs as compared to the two other sectors. These results combined with the earlier observations in this paper support the conclusion that air masses related to the highest VMRs of long-lived VOCs observed at SMEAR II have their origin in Russia and the eastern European countries, the northern part of continental Europe and southern and central Fennoscandia.

\section{Conclusions}

This study has focused on identifying the source areas of the long-lived VOCs (methanol, acetonitrile, acetaldehyde, acetone, benzene, and toluene) measured at the SMEAR II site in southern Finland, and to investigate the relative influences of biogenic and anthropogenic sources to compounds arriving to southern Finland from areas outside of the country. The analysis is based on a data set which consisted of several years (2006-2011) of VMR measurements of VOC. The origin and sources of the observed VOCs were analyzed by the trajectory model and a multivariate receptor model.

During the measurement period, two major forest fire episodes occurred in Russia. Elevated VMR levels for several VOCs and other trace gases were observed in air masses arriving from areas in which abundant fire counts were 

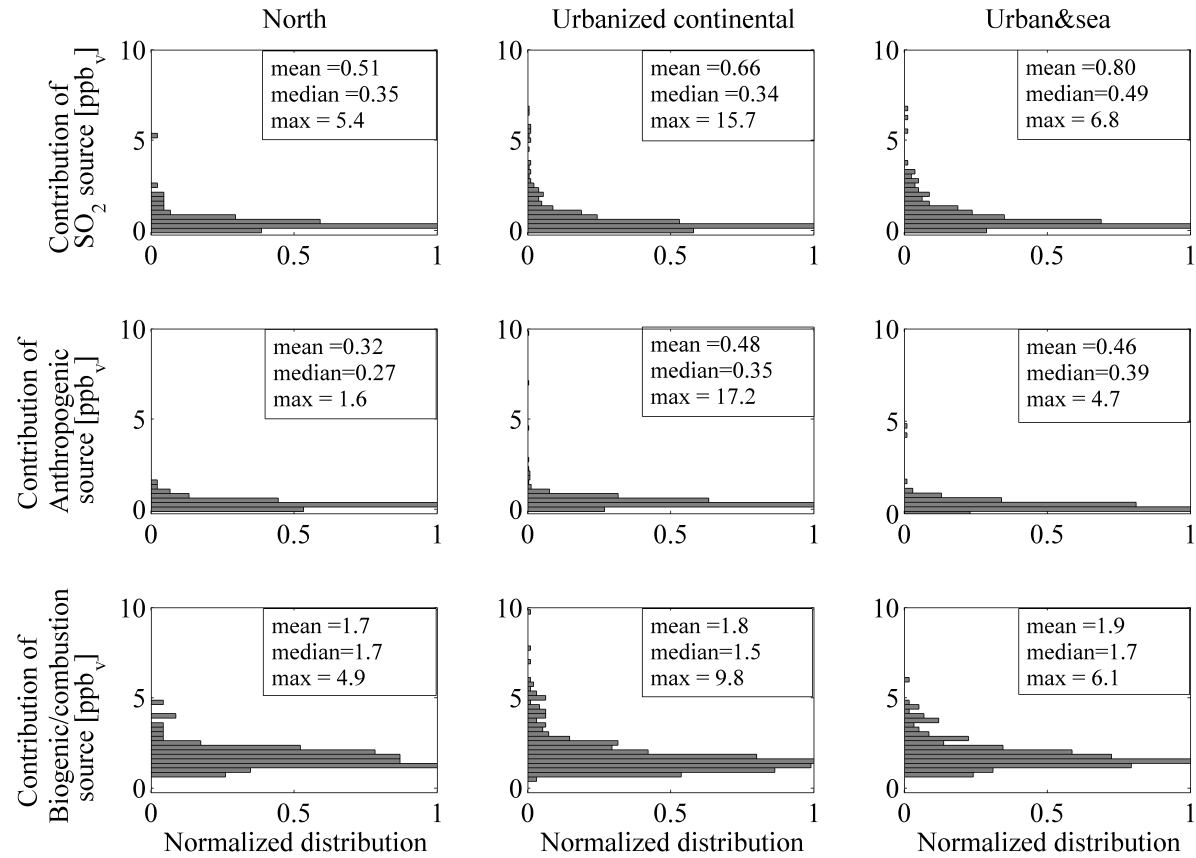

Figure 10. Normalized distributions of different sources in three sectors during the summer. The first column is the north sector $(N=338)$, the second column is the urbanized continental sector $(N=1817)$ and the third column is the urban and sea sector $(N=952)$. In the topmost row all panels are distributions of the $\mathrm{SO}_{2}$ source, the middle row the anthropogenic source and the lowest row biogenic/combustion source. Each sector has been normalized with the maximum value of the observations. Mean, median, and maximum values of source contributions are shown for each sector.
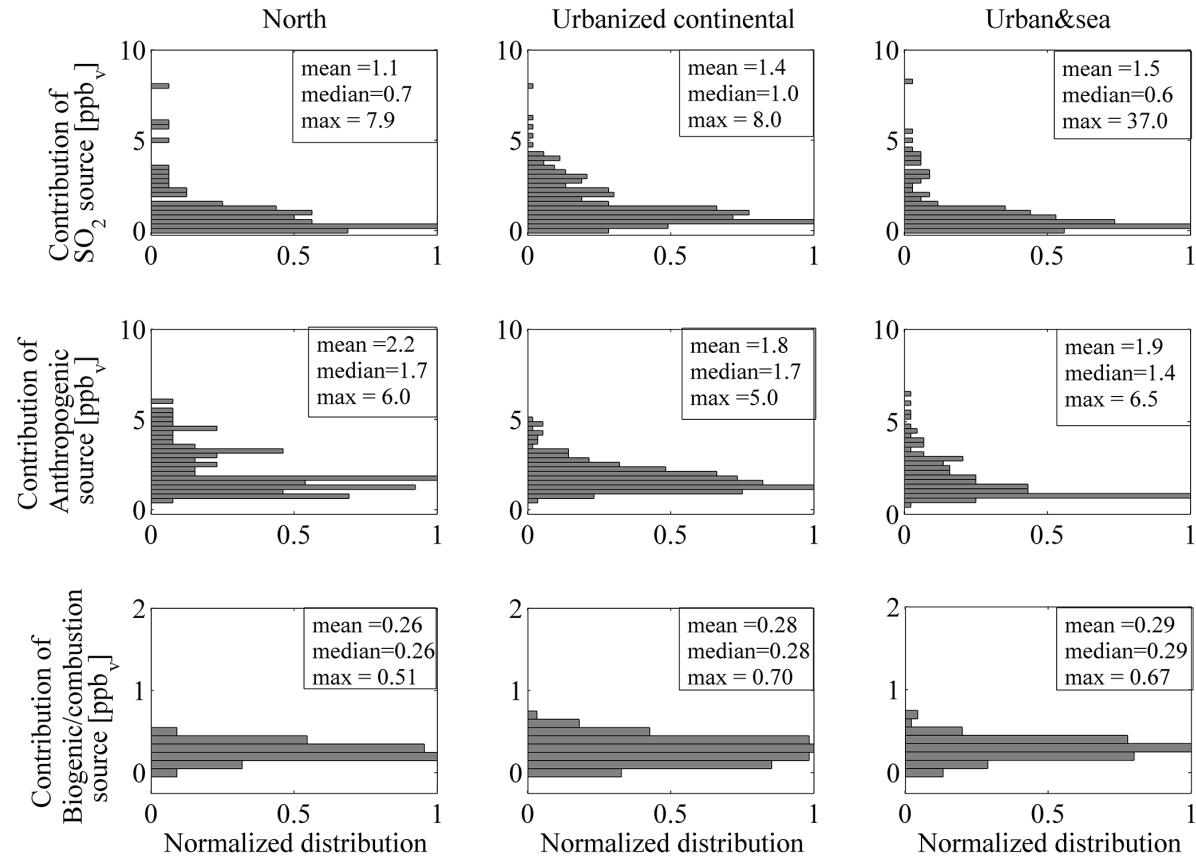

Figure 11. Normalized distributions of different sources in three sectors during the winters. The first column is the north sector $(N=142)$, the second column is the urbanized continental sector $(N=714)$ and the third column is the urban and sea sector $(N=391)$. In the topmost row all panels are distributions of the $\mathrm{SO}_{2}$ source, the middle row the anthropogenic source and the lowest row the biogenic/combustion source. Each sector has been normalized with the maximum value of the observations. Mean, median, and maximum values of source contributions are shown for each sector. 
observed. This corroborates the applicability of the trajectory analysis as a method for identifying the source areas of these trace gases.

The trajectory analysis indicated the importance of especially eastern Europe and Russia for elevated VMRs of long-lived VOCs in southern Finland, and lack of significant sources in Scandinavia and North Sea.

Three sources (labelled $\mathrm{SO}_{2}$, biogenic/combustion and anthropogenic) were identified by receptor analysis both in winter and summer. The biogenic/combustion source dominated in summer and the anthropogenic source in winter. Both the trajectory and Unmix analyses showed that air masses coming from a northerly direction had fewer pollution events with the studied trace gases than the air-masses arriving from easterly and westerly directions with higher anthropogenic influence.

The long-range transport from easterly directions may explain at least partly the lack of declining trend in the VOC VMRs observed here and by Hellén et al. (2015) in northern Finland, in spite of emission reductions in European Union. The result stresses the importance of global emission reductions for cleaner air.

The 10 source areas selected for further analysis showed enhanced emissions due to the anthropogenic activity: most of the areas contained industrial activity. There were some differences in the importance of these source areas between summer and winter. western Russia, northern Poland, Kaliningrad and the Baltic regions and Karelia turned out to be the most significant source area for all the VOCs. Benzene came mainly from areas related to the petrochemical industry, such as the Kola Peninsula, while acetone and acetaldehyde were related to areas where solvents are used in industry e.g. the Skagerrak and northern Germany. Forest fire areas stood out clearly as sources for all the studied VOCs and especially for acetonitrile. This study showed that forest fires can cause elevated levels of atmospheric VOCs hundreds of kilometres downwind, and can pose a threat to the air quality. With changing climate the frequency and strength of forest fires are expected to increase. Thus any efforts to prevent forest fires or develop early detection and extinguishing methods would be beneficial for future air quality and health. Even though boreal forests with their high OVOC emissions cover large areas in the region, these forest areas were not specifically indicated as source areas. However, they probably did contribute to the regional background levels. The level of $\mathrm{SO}_{2}$ concentration showed a clear difference between eastern and western European source areas, which was not seen in water soluble VOCs. Thus, the difference in the $\mathrm{SO}_{2}$ can be attributed to reduction of its emissions in western Europe. 


\section{Appendix A}

Table A1. Main industries of source areas.

\begin{tabular}{|c|c|c|}
\hline Source area & Main industries & $\begin{array}{l}\text { Mean population } \\
\text { density of area } \\
\text { [persons } \mathrm{km}^{-2} \text { ] }\end{array}$ \\
\hline 1. Western Russia & $\begin{array}{l}\text { Oil and gas trade, shipbuilding yards, machine building, heavy } \\
\text { machinery, mining, ferrous and nonferrous metallurgy, chemical } \\
\text { industry and energy and paper production }{ }^{1}\end{array}$ & 55 \\
\hline $\begin{array}{l}\text { 2. Northern Poland, } \\
\text { Kaliningrad and } \\
\text { Baltic countries }\end{array}$ & $\begin{array}{l}\text { Machinery and chemical industry: chemicals, petroleum and refining, } \\
\text { shipbuilding and coal mining }{ }^{2} \text {, forestry with wood and processed wood } \\
\text { products, chemical, pharmaceuticals, plastic and rubber industry, metal } \\
\text { and electronics industry }{ }^{3}\end{array}$ & 63 \\
\hline $\begin{array}{l}\text { 3. Karelia and } \\
\text { White Sea }\end{array}$ & $\begin{array}{l}\text { Forest industry, ferrous and non-ferrous metallurgy, coastal areas of } \\
\text { the White Sea: oil production and processing }{ }^{4}\end{array}$ & 3 \\
\hline $\begin{array}{l}\text { 4. Kola Peninsula } \\
\text { and Barents Sea }\end{array}$ & $\begin{array}{l}\text { Mining, iron industry (iron-ore enterprises and separators), apatite } \\
\text { production and other metal industry such as aluminum and nickel } \\
\text { plants and smelters } 5 \text {, petroleum industry } 6\end{array}$ & 5 \\
\hline 5. Bay of Bothnia & Metallurgy and wood and timber industry ${ }^{7}$ & 15 \\
\hline $\begin{array}{l}\text { 6. Coast of } \\
\text { Norwegian Sea } \\
\text { and Northern } \\
\text { Sweden }\end{array}$ & Machinery, metal industry and mining 7,8 & 3 \\
\hline 7. Stockholm area & Electronics and chemical industry, machinery ${ }^{7}$ & 48 \\
\hline 8. Skagerrak & Machinery, metallurgy and chemical industry ${ }^{7}$ & 117 \\
\hline $\begin{array}{l}\text { 9. North Sea } \\
\text { and coastal areas }\end{array}$ & Oil production ${ }^{9}$ & 358 \\
\hline 10. Northern Germany & $\begin{array}{l}\text { Chemicals, plastics, electronics and automotive industry }{ }^{10} \text {, dockyards } \\
\text { for shipbuilding, metal industry and machinery }{ }^{11}\end{array}$ & 203 \\
\hline
\end{tabular}




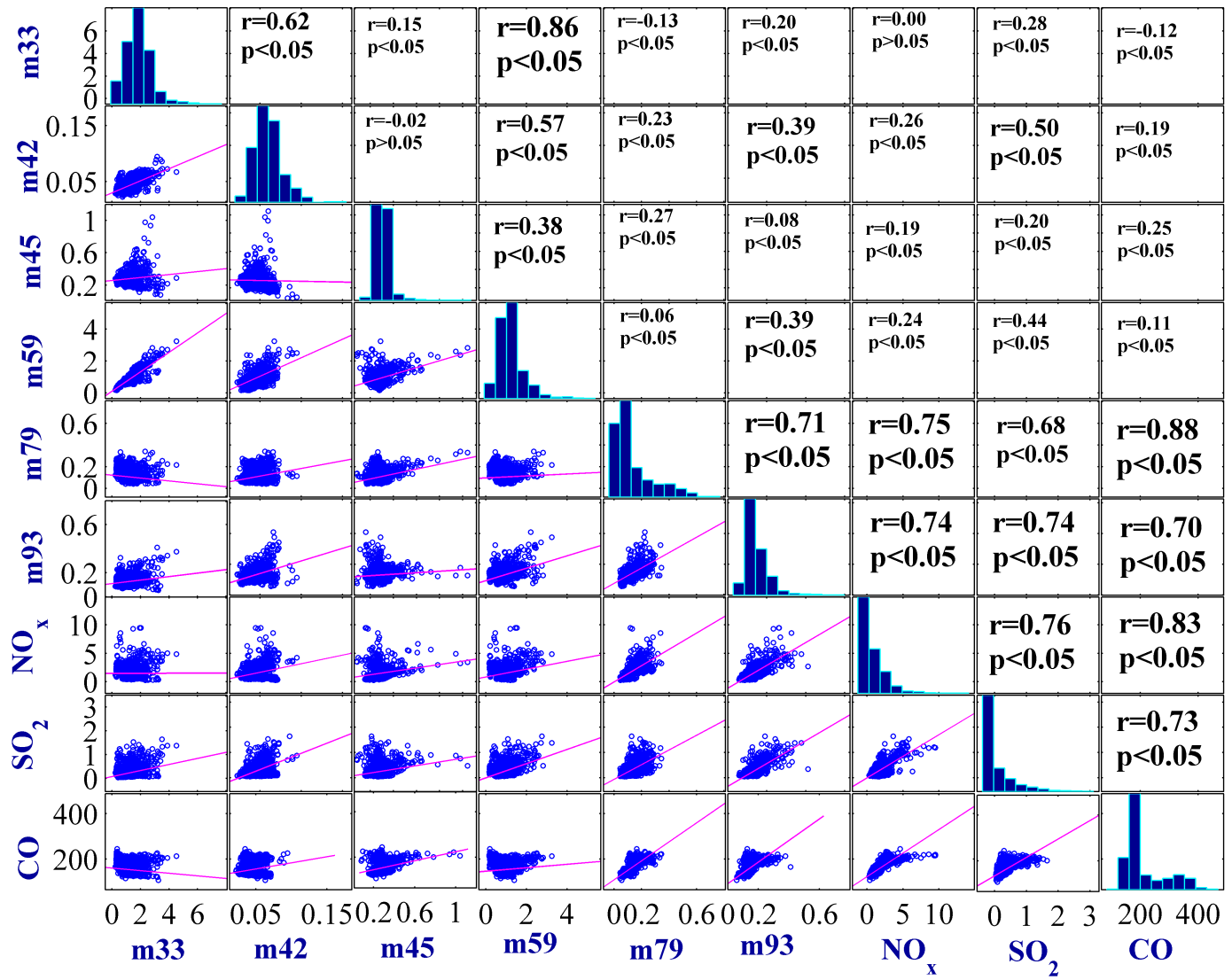

Figure A1. The correlation matrix, Pearson's correlation coefficients and $p$ values between calculated trace gases ( $m 33$ (methanol) $m 42$ (acetonitrile) $m 45$ (acetaldehyde) $m 59$ (acetone) $m 79$ (benzene) $m 93$ (toluene) $\mathrm{NO}_{x}$ (nitrogen oxides) $\mathrm{CO}$ (carbon monoxide) and $\mathrm{SO}_{2}$ (sulfur dioxide)) correlations. Diagonal in the matrix is distribution of data. 


\section{The Supplement related to this article is available online at doi:10.5194/acp-15-13413-2015-supplement.}

Acknowledgements. This work was financially supported by the Academy of Finland Centre of Excellence program (projects 1118615 and 272041) and the Nordic Centre of Excellence CRAICC. The authors thank H. Hellén for helping in the photolysis rate calculations. NASA MODIS is acknowledged for providing data at the data server.

Edited by: S. M. Noe

\section{References}

Anttila, P., Makkonen, U., Hellén, H., Kyllönen, K., Leppänen, S., Saari, H., and Hakola, H.: Impact of the open biomass fires in spring and summer of 2006 on the chemical composition of background air in south-eastern Finland, Atmos. Environ., 42, 64726486, 2008.

Artic Centre, University of Lapland: Main industrial centers in North-West Russia, available at: http://arcticcentre.ulapland.fi/ maps.asp (last access: 13 January 2014), 2005.

Atkinson, R.: Gas-phase tropospheric chemistry of organic compounds, J. Phys. Chem. Ref. Data Monogr., 2, 1-216, 1994.

Atkinson, R. and Arey, J.: Atmospheric degradation of volatile organic compounds, Chem. Rev., 103, 4605-4638, 2003.

Austvik, O. G.: The geopolitics of Barents Sea oil and gas: the mouse and the bear, International association of energy economics (IAEE), Cleaveland, USA, available at: http://www.iaee. org/documents/newsletterarticles/Gunnar.pdf (last access: 5 May 2014), 2007.

Bäck, J., Aalto, J., Henriksson, M., Hakola, H., He, Q., and Boy, M.: Chemodiversity of a Scots pine stand and implications for terpene air concentrations, Biogeosciences, 9, 689-702, doi:10.5194/bg-9-689-2012, 2012.

Baker, A. K., Beyersdorf, A. J., Doezema, L. A., Katzenstein, A., Meinardi, S., Simpson, I. J., Blake, D. R., and Sherwood Rowland, F.: Measurement of nonmethane hydrocarbons in 28 United States cities, Atmos. Environ., 42, 170-182, 2008.

Blake, R. S., Monks, P. S., and Ellis, A. M.: Proton-transfer reaction mass spectrometry, Chem. Rev., 109, 861-896, 2009.

Bothnian green logistics corridor: new boost for European industrial future, available at: http://www. bothniangreen.se/wp-content/uploads/2012/12/\%E2\%80\%

93-New-boost-for-European-industrial-future.pdf (last access: 25 April 2014) 2012.

Crutzen, P. and Andreae, M. O.: Biomass burning in the Tropics: impact of atmospheric chemistry and biogeochemical cycles, Science, 250, 1669-1678, 1990.

de Gouw, J. and Warneke, C.: Measurements of volatile organic compounds in the earth's atmosphere using proton-transferreaction mass spectrometry, Mass. Spectrom. Rev., 26, 223-257, 2007.

de Gouw, J., Warneke, C., Karl, T., Eerdekens, G., van der Veen, C., and Fall, R.: Sensitivity and specificity of atmospheric trace gas detection by proton-transfer-reaction mass spectrometry, Int. J. Mass. Spectrom., 223-224, 265-382, 2003.

de Gouw, J. A., Warneke, C., Stohl, A., Wollny, A. G., Brock, C. A., Cooper, O. R., Holloway, J. S., Trainer, M., Fehsenfeld, F. C., Atlas, E.L, Donnely, S. G., Stroud, V., and Lueb, A.: Volatile organic compounds composition of merged and aged forest fire plumes from Alaska and western Canada, J. Geophys. Res., 111, D10303, doi:10.1029/2005JD006175, 2006.

Draxler, R. R. and Hess, G. D.: An overview of the HYSPLIT_4 modelling system for trajectories, dispersion and deposition, Aust. Meteorol. Mag., 47, 295-308, 1998.

Eerdekens, G., Yassaa, N., Sinha, V., Aalto, P. P., Aufmhoff, H., Arnold, F., Fiedler, V., Kulmala, M., and Williams, J.: VOC measurements within a boreal forest during spring 2005: on the occurrence of elevated monoterpene concentrations during night time intense particle concentration events, Atmos. Chem. Phys., 9, 8331-8350, doi:10.5194/acp-9-8331-2009, 2009.

Ehn, M., Thornton, J. A., Kleist, E., Sipilä, M., Junninen, H., Pullinen, I., Springer, M., Rubach, F., Tillmann, R., Lee, B., Lopez-Hilfiker, F., Andres, S., Acir, I.-H., Rissanen, M., Jokinen, T., Schobesberger, S., Kangasluoma, J., Kontkanen, J., Nieminen, T., Kurtén, T., Nielsen, L. B., Jørgensen, S., Kjaergaard, H. G., Canagaratna, M., Dal Maso, M., Berndt, T., Petäjä, T. Wahner, A., Kerminen,V.-M., Kulmala, M., Worsnop, D. R., Wildt, J., and Mentel, T. F.: A large source of low-volatility secondary organic aerosols, Nature, 506, 476-479, 2014.

EIA: International Energy Outlook, Washington, USA, available at: http://www.eia.gov/forecasts/ieo/pdf/0484\%282014\%29.pdf last access: 6 May 2014.

Fink, P.: Ecological functions of volatile organic compounds in aquatic systems, Mar Freshw. Behav. Phy., 40, 155-168, 2007.

FIRMS MODIS: fires/hotspots observations from archive, available at: https://earthdata.nasa.gov/data/near-real-time-data/firms/ active-fire-data\#tab-content-6 last access: 24 April 2014.

GTAI: Germany's Seaports, Berlin, Germany, available at: http://www.gtai.de/GTAI/Content/EN/Invest/ _SharedDocs/Downloads/GTAI/Brochures/Industries/ germanys-seaports-connecting-europe-with-the-world-en.pdf (last access: 2 April 2014), 2011.

GTAI: Industry Overview, Berlin, Germany, available at: http://www.gtai.de/GTAI/Content/EN/Invest/ _SharedDocs/Downloads/GTAI/Industry-overviews/

industry-overview-machinery-equipment-en.pdf (last access: 2 April 2014), 2013.

Guenther, A., Hewitt, C. N., Erickson, D., Fall, R., Geron, C., Graedel, T., Harley, P., Klinger, L., Lerdau, M., McKay, W. A., Pierce, T., Scholes, B., Steinbrecher, R., Tallamraju, R., Taylor, J., and Zimmerman, P.: A global model of natural volatile organic compound emissions, J. Geophys. Res., 100, 8873-8892, 1995.

Haapanala, S., Rinne, J., Hakola, H., Hellén, H., Laakso, L., Lihavainen, H., Janson, R., O'Dowd, C., and Kulmala, M.: Boundary layer concentrations and landscape scale emissions of volatile organic compounds in early spring, Atmos. Chem. Phys., 7, 1869-1878, doi:10.5194/acp-7-1869-2007, 2007.

Haapanala, S., Hakola, H., Hellén, H., Vestenius, M., Levula, J., and Rinne, J.: Is forest management a significant source of monoter- 
penes into the boreal atmosphere?, Biogeosciences, 9, 12911300, doi:10.5194/bg-9-1291-2012, 2012.

Hakola, H., Laurila, T., Rinne, J., and Puhto, K.: The ambient concentrations of biogenic hydrocarbons at a North-European site, Atmos. Environ., 34, 4971-4982, 2000.

Hakola, H., Tarvainen, V., Laurila, T., Hiltunen, V., Hellén, H., and Keronen, P.: Seasonal variation of VOC concentrations above a boreal coniferous forest, Atmos. Environ., 37, 1623-1634, 2003.

Hakola, H., Hellén, H., Tarvainen, V., Bäck, J., Patokoski, J., and Rinne, J.: Annual variations of atmospheric VOC concentrations in a boreal forest, Boreal Environ. Res., 14, 722-730, 2009.

Hakola, H., Hellén, H., Hemmilä, M., Rinne, J., and Kulmala, M.: In situ measurements of volatile organic compounds in a boreal forest, Atmos. Chem. Phys., 12, 11665-11678, doi:10.5194/acp12-11665-2012, 2012

Hansen, E. and Tønnessen, A.: Environment and living conditions on the Kola Peninsula, Fafo-report 260, Fafo Institute for Applied Social Science, Oslo, Norway, 1998.

Hari, P. and Kulmala, M.: Station for measuring ecosystem - atmosphere relations (SMEAR II), Boreal Environ. Res., 10, 315-322, 2005.

Hellén, H., Hakola, H., and Laurila, T.: Determination of source contributions of NMHCs in Helsinki $\left(60^{\circ} \mathrm{N}, 25^{\circ} \mathrm{E}\right)$ using chemical mass balance $(\mathrm{CMB})$ and the Unmix multivariate receptor models, Atmos. Environ., 37, 1413-1424, 2003.

Hellén, H., Hakola, H., Reissell, A., and Ruuskanen, T. M.: Carbonyl compounds in boreal coniferous forest air in Hyytiälä, Southern Finland, Atmos. Chem. Phys., 4, 1771-1780, doi:10.5194/acp-4-1771-2004, 2004.

Hellén, H., Hakola, H., Pirjola, L., Laurila, T., and Pystynen, K.H.: Ambient air concentrations, source profiles and source apportionment of 71 different $\mathrm{C}_{2}-\mathrm{C}_{10}$ volatile organic compounds in urban and residential areas of Finland, Environ. Sci. Technol., 40, 103-108, 2006.

Hellén, H., Kouznetsov, R., Anttila, P., and Hakola, H.: Increasing influence of easterly air masses on NMHC concentrations at the Pallas-Sodankylä GAW station, Boreal Env. Res., 20, 542-552, 2015.

Holzinger, R., Warneke, C., Hansel, A., Jordan, A., Lindinger, W., Scharffe, D. H., Schade, G., and Crutzen, P. J.: Biomass burning as a source of formaldehyde, acetaldehyde, methanol, acetone, acetonitrile, and hydrogen cyanide, Geophys. Res. Lett., 26, 1161-1164, 1999.

Intership to industry: The Industrial Sector in Sweden, available at: http://internship2industry.eu/tools/IndustrialSectorSweden.pdf (last access: 5 May 2014), Gothenburg, Sweden, 2009.

Jacob, D. J., Field, B. D., Li, Q., Blake, D. R., de Gouw, J., Warneke, C., Hansel, A., Wisthaler, A., Singh, H. B., and Guenther, A.: Global budget of methanol: Constraints from atmospheric observations, J. Geophys. Res., 110, D08303, doi:10.1029/2004JD005172, 2005.

Kajos, M. K., Rantala, P., Hill, M., Hellén, H., Aalto, J., Patokoski, J., Taipale, R., Hoerger, C. C., Reimann, S., Ruuskanen, T. M., Rinne, J., and Petäjä, T.: Ambient measurements of aromatic and oxidized VOCs by PTR-MS and GC-MS: intercomparison between four instruments in a boreal forest in Finland, Atmos. Meas. Tech., 8, 4453-4473, doi:10.5194/amt-8-4453-2015, 2015.
Kansal, A.: Sources and reactivity of NMHCs and VOCs in the atmosphere: a review, J. Hazard. Mater., 166, 17-26, 2009.

Koppmann, R. and Wildt, J.: Oxygenated Volatile Organic Compounds, edited by: Koppmann, R., Blackwell Publishing Ltd., Oxford, UK, 2007.

Lappalainen, H. K., Sevanto, S., Bäck, J., Ruuskanen, T. M., Kolari, P., Taipale, R., Rinne, J., Kulmala, M., and Hari, P.: Daytime concentrations of biogenic volatile organic compounds in a boreal forest canopy and their relation to environmental and biological factors, Atmos. Chem. Phys., 9, 5447-5459, doi:10.5194/acp-9-5447-2009, 2009.

Leino, K., Riuttanen, L., Nieminen, T., Dal Maso, M., Väänänen, R., Pohja, T., Keronen, P., Järvi, L., Aalto, P. P., Virkkula, A., Kerminen, V.-M., Petäjä, T., and Kulmala, M.: Biomass-burning smoke episodes in Finland from eastern European wildfires, Boreal Environ. Res., 19, 265-292, 2014.

Liao, L., Dal Maso, M., Taipale, R., Rinne, J., Ehn, M., Junninen, H., Äijälä, M., Nieminen, T., Alekseychik, P., Hulkkonen, M., Worsnop, D. R., Kerminen, V.-M., and Kulmala, M.: Monoterpene pollution episodes in a forest environment: indication of anthropogenic origin and association with aerosol particles, Boreal Environ. Res., 16, 288-303, 2011.

Lindinger, W., Hansel, A., and Jordan, A.: On-line monitoring of volatile organic compounds at pptv levels by means of protontransfer-reaction mass spectrometry (PTR-MS) medical applications, food control and environmental research, Int. J. Mass. Spectrom., 173, 191-241, 1998a.

Lindinger, W., Hansel, A., and Jordan, A.: Proton-transfer-reaction mass spectrometry (PTR-MS): on-line monitoring of volatile organic compounds at pptv levels, Chem. Soc. Rev., 27, 347-354, 1998b.

Norris, G., Vedentham, R., and Duvall, R.: EPA Unmix 6.0 Fundamentals \& User Guide, US Environmental Protection Agency, Office of Research and Development, Washington, DC 20460, 2007.

Patokoski, J., Ruuskanen, T. M., Hellén, H., Taipale, R., Grönholm, T., Kajos, M. K., Petäjä, T., Hakola, H., Kulmala, M., Rinne, J.: Winter to spring transition and diurnal variation of VOCs in Finland at an urban background site and a rural site, Boreal Environ. Res., 19, 79-103, 2014.

Reimann, S. and Lewis, A. C.: Anthropogenic VOCs, edited by: Koppmann, R., Blackwell Publishing Ltd., Oxford, UK, 2007.

Ria Novosti: Russian Industry Against the Backdrop of the Economic Crisis, available at: http://en.ria.ru/infographics/ 20100408/158486046.html (last access: 3 April 2014), Moscow, Russia, 2010.

Rinne, J., Ruuskanen, T. M., Reissell, A., Taipale, R., Hakola, H., and Kulmala, M.: On-line PTR-MS measurements of atmospheric concentrations of volatile organic compounds in a European boreal forest ecosystem, Boreal Environ. Res., 10, 425-436, 2005.

Rinne, J., Taipale, R., Markkanen, T., Ruuskanen, T. M., Hellén, H., Kajos, M. K., Vesala, T., and Kulmala, M.: Hydrocarbon fluxes above a Scots pine forest canopy: measurements and modeling, Atmos. Chem. Phys., 7, 3361-3372, doi:10.5194/acp-73361-2007, 2007.

Rinne, J., Markkanen, T., Ruuskanen, T. M., Petäjä, T., Keronen, P., Tang, M.J., Crowley, J. N., Rannik, Ü., and Vesala, T.: Effect of chemical degradation on fluxes of reactive compounds - a study 
with a stochastic Lagrangian transport model, Atmos. Chem. Phys., 12, 4843-4854, doi:10.5194/acp-12-4843-2012, 2012.

Riuttanen, L., Hulkkonen, M., Dal Maso, M., Junninen, H., and Kulmala, M.: Trajectory analysis of atmospheric transport of fine particles, $\mathrm{SO}_{2}, \mathrm{NO}_{\mathrm{x}}$ and $\mathrm{O}_{3}$ to the SMEAR II station in Finland in 1996-2008, Atmos. Chem. Phys., 13, 2153-2164, doi:10.5194/acp-13-2153-2013, 2013.

Ruuskanen, T. M., Kolari, P., Bäck, J., Kulmala, M., Rinne, J., Hakola, H., Taipale, R., Raivonen, M., Altimir, N., and Hari, P.: On-line field measurements of monoterpene emissions from Scots pine by proton-transfer-reaction mass spectrometry, Boreal Environ. Res., 10, 553-567, 2005.

Ruuskanen, T. M., Taipale, R., Rinne, J., Kajos, M. K., Hakola, H., and Kulmala, M.: Quantitative long-term measurements of VOC concentrations by PTR-MS: annual cycle at a boreal forest site, Atmos. Chem. Phys. Discuss., 9, 81-134, doi:10.5194/acpd-981-2009, 2009.

Seinfeld, J. H. and Pandis, S. N.: Atmospheric Chemistry and Physics: From Air Pollution to Climate Change, WileyInterscience, New York, 1998.

Simpson, D., Winiwarter, W., Börjesson, G., Cinderby, S., Ferreiro, A., Guenther, A., Hewitt, C. N., Janson, R., Khalil, M. A. K., Owen, S., Pierce, T. E., Puxbaum, H., Shearer, M., Skiba, U., Steinbrecher, R., Tarrasón, L., and Öquist, M. G.: Inventorying emissions from nature in Europe, J. Geophys. Res., 104, 8113-8152, 1999.

Simpson, I. J., Akagi, S. K., Barletta, B., Blake, N. J., Choi, Y., Diskin, G. S., Fried, A., Fuelberg, H. E., Meinardi, S., Rowland, F. S., Vay, S. A., Weinheimer, A. J., Wennberg, P. O., Wiebring, P., Wisthaler, A., Yang, M., Yokelson, R. J., and Blake, D. R.: Boreal forest fire emissions in fresh Canadian smoke plumes: $\mathrm{C}_{1}-\mathrm{C}_{10}$ volatile organic compounds (VOCs), $\mathrm{CO}_{2}, \mathrm{CO}, \mathrm{NO}_{2}$, $\mathrm{NO}, \mathrm{HCN}$ and $\mathrm{CH}_{3} \mathrm{CN}$, Atmos. Chem. Phys., 11, 6445-6463, doi:10.5194/acp-11-6445-2011, 2011.

Singh, H. B., Salas, L. J., Chatfield, R. B., Czech, E., Fried, A., Walega, J., Evans, M. J., Field, B. D., Jacob, D. J., Blake, D., Heikes, B., Talbot, R., Sachse, G., Crawford, J. H., Avery, M. A., Sandholm, S., and Fuelberg, H.: Analysis of the atmospheric distribution, sources, and sinks of oxygenated volatile organic chemicals based on measurements over the Pacific during TRACE-P, J. Geophys. Res., 109, D15S07, doi:10.1029/2003JD003883, 2004.

Stohl, A.: Trajectory statistics - a new method to establish sourcereceptor relationships of air pollutants and its application to the transport of particulate sulfate in Europe, Atmos. Environ., 30, 579-587, 1996.

Stohl, A. and Seibert, P.: Accuracy of trajectories as determined from the conservation of meteorological tracers, Q. J. Roy. Meteor. Soc., 124, 1465-1484, 1998.

Stohl, A., Wotawa, G., Seibert, P., and Kromp-Kolb, H.: Interpolation errors in wind fields as a function of spatial and temporal resolution and their impact on different types of kinematic trajectories, J. Appl. Meteorol., 34, 2149-2165, 1995.
Taipale, R., Ruuskanen, T. M., Rinne, J., Kajos, M. K., Hakola, H., Pohja, T., and Kulmala, M.: Technical Note: Quantitative long-term measurements of VOC concentrations by PTR-MS measurement, calibration, and volume mixing ratio calculation methods, Atmos. Chem. Phys., 8, 6681-6698, doi:10.5194/acp8-6681-2008, 2008.

Tani, A., Hayward, S., and Hewitt, C. N.: Measurement of monoterpenes and related compounds by proton-transfer-reaction mass spectrometer (PTR-MS), Int. J. Mass. Spectrom., 223-224, 561578, 2003.

Tunved, P., Hansson, H.-C., Kerminen, V.-M., Ström, J., Dal Maso, M., Lihavainen, H., Viisanen, Y., Aalto, P. P., Komppula, M., and Kulmala, M.: High natural aerosol loading over boreal forests, Science, 312, 261-263, 2006.

Twardosz, R. and Kossowska-Cezak, U.: Exceptionally hot summers in Central and Eastern Europe (1951-2010), Theor. Appl. Climatol., 112, 617-628, 2013.

Vesala, T., Haataja, J., Aalto, P. P., Altimir, N., Buzorius, G., Hämeri, K., Ilvesniemi, H., Jokinen, V., Keronen, P., Lahti, T., Markkanen, T., Mäkelä, J. M., Nikinmaa, E., Palmroth, S., Pohja, T., Pumpanen, J., Rannik, U., Siivola, E., Ylitalo, H., Hari, P., and Kulmala, M.: Long-term field measurements of atmospheresurface interaction in boreal forest combining forest ecology, micrometeorology, aerosol physics and atmospheric chemistry, Trends Heat Mass Moment. Transf., 4, 17-35, 1998.

Vestreng, V., Myhre, G., Fagerli, H., Reis, S., and Tarrasón, L.: Twenty-five years of continuous sulphur dioxide emission reduction in Europe, Atmos. Chem. Phys., 7, 3663-3681, doi:10.5194/acp-7-3663-2007, 2007.

Virkkula, A., Levula, J., Pohja, T., Aalto, P. P., Keronen, P., Schobesberger, S., Clements, C. B., Pirjola, L., Kieloaho, A.-J., Kulmala, L., Aaltonen, H., Patokoski, J., Pumpanen, J., Rinne, J., Ruuskanen, T., Pihlatie, M., Manninen, H. E., Aaltonen, V., Junninen, H., Petäjä, T., Backman, J., Dal Maso, M., Nieminen, T., Olsson, T., Grönholm, T., Aalto, J., Virtanen, T. H., Kajos, M., Kerminen, V.-M., Schultz, D. M., Kukkonen, J., Sofiev, M., De Leeuw, G., Bäck, J., Hari, P., and Kulmala, M.: Prescribed burning of logging slash in the boreal forest of Finland: emissions and effects on meteorological quantities and soil properties, Atmos. Chem. Phys., 14, 4473-4502, doi:10.5194/acp-14-44732014, 2014.

The World Factbook: Russia, available at: https://www.cia.gov/ library/publications/the-world-factbook/geos/rs.html (last access: 3 April 2014), 2014a.

The World Factbook: Poland, available at: https://www.cia.gov/ library/publications/the-world-factbook/geos/pl.html (last access: 3 April 2014), 2014b.

The World Factbook: Industries, available at: https://www.cia.gov/ library/publications/the-world-factbook/fields/2090.html\#pl (last access: 3 April 2014), 2014c. 